\title{
Knowing the Enemy: Inducible Defences in Freshwater Zooplankton
}

\author{
Patricia Diel ${ }^{1, \dagger}$, Marvin Kiene ${ }^{1, \dagger}$, Dominik Martin-Creuzburg ${ }^{2} \mathbb{D}$ and Christian Laforsch ${ }^{1, *}$ \\ 1 Department of Animal Ecology, University of Bayreuth, Universitätsstrasse 30, D-95447 Bayreuth, Germany; \\ patricia.diel@uni-bareuth.de (P.D.); marvin.kiene@uni-bayreuth.de (M.K.) \\ 2 Limnological Institute, University of Konstanz, Mainaustrasse 252, D-78464 Konstanz, Germany; \\ dominik.martin-creuzburg@uni-konstanz.de \\ * Correspondence: Christian.Laforsch@uni-bayreuth.de \\ + These authors contributed equally to this work.
}

Received: 13 March 2020; Accepted: 3 April 2020; Published: 7 April 2020

\begin{abstract}
Phenotypic plasticity in defensive traits is an appropriate mechanism to cope with the variable hazard of a frequently changing predator spectrum. In the animal kingdom these so-called inducible defences cover the entire taxonomic range from protozoans to vertebrates. The inducible defensive traits range from behaviour, morphology, and life-history adaptations to the activation of specific immune systems in vertebrates. Inducible defences in prey species play important roles in the dynamics and functioning of food webs. Freshwater zooplankton show the most prominent examples of inducible defences triggered by chemical cues, so-called kairomones, released by predatory invertebrates and fish. The objective of this review is to highlight recent progress in research on inducible defences in freshwater zooplankton concerning behaviour, morphology, and life-history, as well as difficulties of studies conducted in a multipredator set up. Furthermore, we outline costs associated with the defences and discuss difficulties as well as the progress made in characterizing defence-inducing cues. Finally, we aim to indicate further possible routes in this field of research and provide a comprehensive table of inducible defences with respect to both prey and predator species.
\end{abstract}

Keywords: aquatic ecology; behavioural defences; diel vertical migration; freshwater zooplankton; inducible defences; kairomones; life-history defences; morphological defences; predator-prey interactions

\section{Introduction}

Community diversity is greatly influenced by a variety of selection pressures, one of which is predation (e.g., [1-4]). To increase their fitness, prey species have evolved a variety of defensive mechanisms [5-9]. In general, defences are established as either constitutive or inducible. Constitutive defences are the result of a constant predation pressure, whereas inducible defences are expressed in response to a variable, but at times strong predation risk. The cue signalling the presence of a predator should be reliable and the induction of the defence linked to costs that exceed the benefit in the absence of the respective predator [7,9]. The ability of organisms to form inducible defences in response to environmental changes is based on phenotypic plasticity, i.e., the ability of a genotype to express different phenotypes [10,11]. While immobile plants tend to profit from inducible physiological and morphological defences [8], mobile animals additionally express inducible defences concerning behaviour and life-histories [12]. In freshwater communities, inducible defences have been extensively studied and numerous examples have been documented, highlighting their potential to modulate interactions between organisms and to shape food web processes [13]. Zooplankton are key to transferring carbon and energy from primary producers to higher trophic levels and inducible defences 
in zooplankton may thus crucially influence trophic cascades and the diversity of species $[4,14]$. Throughout the past 50 years, inducible defences were studied in various taxa of zooplankton across the globe (e.g., [15-19]).

Particularly relevant for the induction of defences are chemical cues, so-called kairomones. These are semiochemicals, which predators release unintentionally, signalling the presence of a respective predator to its prey. Generally speaking, they are advantageous for the receiver and disadvantageous for the emitter [20-23]. The phenomenon of thusly induced defences is expressed in fascinating and often striking changes in morphology, life history, and behaviour of various zooplankton species (e.g., [24-31]).

In 2003, Lass and Spaak reviewed inducible antipredator defences in plankton, which is the basis for this review. The studies then, as well as today, predominantly featured species of the genus Daphnia (Branchiopoda: Cladocera), important model organisms in ecology, evolutionary biology, and ecotoxicology. Daphnia are characterized by relatively short generation times and cyclical parthenogenesis, i.e., they shift between asexual and sexual reproduction. Under favorable conditions, Daphnia typically reproduce asexually, rendering all offspring as clones of their mother, which is a great advantage for ecological and evolutionary experiments. Furthermore, some of its species have fully sequenced genomes [32,33]. Results obtained in laboratory studies on these organisms are crucial for reconstructing and understanding ecological processes in nature [34-36].

In this review, we aim to draw attention to the recent progress that has been made in the basic research on inducible defences in freshwater zooplankton. We summarize newly discovered defences as well as aspects that may influence defence induction or expression. We highlight the complications that accompany attempts to design and compare experiments, with special attention to multipredator setups. Additionally, we will discuss recent findings about costs of inducible defences and highlight recent progress in identifying and characterizing defence-inducing cues. However, we do not focus on the evolution, evo-devo, nor genetic and molecular mechanisms underlying inducible defences in zooplankton as they have been reviewed already by Stollewerk [37] and more recently by Weiss et al. [38]. Finally, we point out possible future directions of research and provide a comprehensive table of recent studies (since 2003) on inducible defences in zooplankton (Table A1).

\section{Inducible Defences}

Induced changes in behaviour allow the prey to respond almost instantly to an appearing predation threat. Additionally, behavioural changes are easily reversible if the predator vanishes. Thus, changing the behaviour in response to increased predation risk may be the most beneficial defence strategy in terms of cost-benefit trade-offs. However, behavioural defences of freshwater zooplankton are often complemented with other defences. Firstly, prey can reduce the predation impact by life-history adaptations that counteract the predator's hunting or feeding strategy or compensate for population losses. Secondly, the expression of morphological defences may reduce predation losses as these morphological changes may interfere with the catching and/or feeding process of the predator or may prevent an attack. However, despite a sometimes high genetic variation of traits (e.g., [39-41]), freshwater zooplankton prey show a variety of inducible defences in different traits, between species and between clones. The reasons for this variance may be manifold. Besides natural conditions that might influence the expression of defences (see further below), induced defensive responses might differ according to the species- or clone-specific vulnerability at a certain life stage, with respect to a specific, present predator regime (e.g., [42-45]). A high variance in the temporal and structural alternation of defences within a population with mixed reaction norms, might secure the population's endurance in nature. It may reduce individual costs of defence expression, and additionally provide an array of defences against various predators or other threats (e.g., low food or changing temperatures). Thus, a high variance makes the extinction of the entire population less likely (e.g., $[42,46,47])$. In the following sections, we will highlight new findings and newly discovered aspects of inducible defences in freshwater zooplankton, as well as point out some examples of variation between species and clones. 


\subsection{Behavioural Defences}

The phenomenon of diel vertical migration (DVM) is a well-known defensive behaviour found in a variety of aquatic invertebrates (e.g., [48-51]). It has been studied in cladocerans for more than one century $[52,53]$. During DVM, the prey migrates periodically up and down in the water column to avoid well-lit water layers and thus also visually orientated predators (e.g., fish), or in an opposite direction to the predator, i.e., reversed DVM, avoiding night-hunting phantom midge larvae (Chaoborus). A reversed DVM may also provide protection against hunting strategies of both predators (fish and Chaoborus) when fish show a similar migration pattern to that of Chaoborus [54]. Even without prior exposure to a predator, Daphnia are capable of responding to the appearance of a new predator with DVM, as has been shown for the invasive predator Bythotrephes [55]. This may indicate a general capacity to respond to introduced predators or a similarity of predator cues within a predator guild (e.g., invertebrates). Nevertheless, studies show ambiguous results for zooplankton species exhibiting DVM only under certain predator regimes. Some respond to Chaoborus, some to fish, and others to both, while some do not exhibit DVM at all (e.g., [44,56-58]). Within the past 17 years, diverse factors have been found to impact DVM, rendering this behaviour a good example of the extraordinarily high complexity of inducible defences in zooplankton.

There are three factors that have been found to specifically affect DVM and that are highly linked with seasonal variation throughout the year: light, food, and temperature. The rate of change in light intensity (i.e., at dusk or dawn) is an important proximate factor controlling DVM [59] to avoid predator encounters. Thereby, a high rate of change in light intensity increases the migration velocity (downwards when light intensity increases, upwards when light intensity decreases). The slower the change in light intensity is, the slower is the vertical movement of the daphnids, until they stay at a certain depth [59]. This pattern of accelerated movement under increased rate of change in light intensity was also found with increased UV-radiation, which led to a prolonged sojourn of Daphnia in deeper water, because they reach the deep water earlier and start migrating upwards later $[60,61]$. Additionally, young daphnids have been shown to respond more strongly than adults to UV-radiation [62-64], which has been reported for predator avoidance by DVM as well [44,61]. Despite this, zooplankton is able to increase pigmentation to protect itself against UV-radiation (see further below) $[33,65,66]$. Thus, the ultimate factor for DVM in response to both UV-radiation and light intensity is the increase in predation risk due to increased visibility to visually hunting predators.

At low food concentrations, while under fish exposure, Daphnia show a tendency to stay in upper water layers, where food is more abundant and the temperature is higher $[49,59]$. This risky behaviour is not found at high food densities, suggesting that food availability is an important factor with respect to DVM [49]. The low temperature in deeper water layers, resulting in a slowdown of development, has been proposed to be an important cost factor of DVM [67]. It seems, however, that Daphnia are more likely to move to deeper, low-temperature water layers at high food densities [67]. Therefore, Daphnia trade a short development time for safety in the deep only under sufficient food supply. Besides food quantity, food quality, mediated by primary producers [68-71], has been shown to affect the strength of DVM and maybe also the capability to perform DVM [72,73]. Laboratory experiments with Daphnia and vertebrate predators suggest that the amplitude of DVM and the capacity to cope with DVM-related temperature fluctuations is affected by the availability of long-chain polyunsaturated fatty acids (PUFAs) in phytoplankton [74-76]. Daphnia, similar to most other animals, lack the capacity to synthesize PUFAs de novo and thus rely on an adequate dietary PUFA supply. PUFAs play an important role in membrane temperature adaptation [77] and seem to be crucial for the performance at low temperatures [78]. Thus, the capability to cope with the low temperatures found in deeper water strata may depend on an adequate dietary PUFA supply in the upper water layers [72,73], i.e., the presence of PUFA-rich phytoplankton species. The potential of PUFAs to constrain DVM under field conditions remains to be studied.

On the one hand, food and temperature are crucial for the growth and development of zooplankton. On the other hand, a response to light and UV-radiation may comprise a trade-off between protection 
against UV-radiation (e.g., by pigmentation) and the increase in vulnerability (due to increased visibility) to visually hunting predators $[33,65,66]$. Winder et al. [60] proposed that temperature and food abundance modulate the depth selection in Daphnia, while predator kairomones and UV-radiation modulate the timing of the DVM (i.e., synchronizing with dusk and dawn), emphasizing the importance of considering these factors in experiments.

Besides light, food, and temperature, other factors have been found to impact DVM, one of which is competition. Gliwicz et al. [79] showed that distribution patterns of Daphnia are also influenced by cues released by prey during crowding (high density of organisms per unit of water). The authors hypothesized that daphnids seek refuge in deeper water layers with lower population densities to profit from higher per capita food concentrations. Adamczuk [80], as well as Dawidowicz and Wielanier [81], also proposed a change in depth-selection due to competition for food, where large species that exhibit DVM lose competitive superiority over small, nonmigrating species [81]. However, those might be more susceptible to fish predation, as indicated by the results of a field study investigating the gut content of young perch, which revealed that only smaller prey individuals $(<1.75 \mathrm{~mm})$ had been eaten [82]. Nevertheless, depending on the size of predatory fish, it might be beneficial for the prey to suspend DVM, to benefit from access to higher food levels throughout night and day. Thus, the depth distribution of the prey may be additionally based on individual prey size [83], and it is either beneficial to grow small to be visually inconspicuous or to grow large to escape the preferred size range of the predator. Therefore, competition for food and individual prey size might modulate the vertical distribution pattern of zooplankton under size-selective predation pressure.

As demonstrated by Gélinas et al. [82] with young perch, not only the prey size but also the predator size seems to matter for the expression of DVM. Evidence for this has been shown by Young and Riessen [84] in mesocosms and by Lagergren et al. [26] in a field study, both suggesting that Bosmina and Daphnia species are flexible in their depth-selection, depending on the size and larval instar of two Chaoborus species. During times when third instar larvae of larger Chaoborus species or fourth-instar larvae of smaller Chaoborus avoided the surface layer up to $1 \mathrm{~m}$ depth, the cladocerans used this water layer as a refuge. At times when fourth instar larvae of smaller Chaoborus species or third instar larvae of larger Chaoborus were hunting at this depth, prey organisms avoided this water layer to evade their predators. Depth selection of Chaoborus larvae in nature is commonly related to fish predation. However, in the mesocosm experiment of Young and Riessen [84], where daphnids responded to differently sized Chaoborus species, no fish were present. Hence, cladocerans seem to be capable of responding even to larvae of different Chaoborus species, and/or to larvae at different developmental stages $[26,84]$. The potential recognition of predator size by the prey is in concordance with a study on crayfish, showing that crayfish are able to respond differently to specific predator sizes [85], pointing towards a high complexity of defence-inducing cues (see below). Thus, it is reasonable to assume that such a mechanism for predator-size-specific responses also evolved in other species such as freshwater dwelling zooplankters. Therefore, future studies should include predator size and developmental stage to get a more detailed insight into predator-induced DVM.

Instead of DVM, some zooplankton species exhibit horizontal migration (e.g., [86,87]), which may be the same response as the so-called habitat selection $[88,89]$. Daphnids as well as mysids select habitats with less vegetation, meaning open water, when exposed to kairomones of damselfly larvae (i.e., Ischnura), since these are ambush predators hiding in the vegetation $[88,89]$. In contrast, they avoid open water in the presence of Chaoborus larvae [88], which are ambush predators that occur mainly in the epilimnion, and seek refuge in littoral waters with macrophytes, even though Daphnia seem to prefer sediment instead of macrophytes [90]. These findings further indicate that the prey is capable of sensing or estimating where predators are present or hunt, and where predation risk is low. In this context, Gutierrez et al. [91] showed that Ceriodaphnia dubia avoids places of predatory cue origin. Likewise, species of the rotifer Brachionus increase the propensity of surface attachment, among others on the carapace of Daphnia, when exposed to the predatory rotifer Asplanchna, the first record of inducible behavioural defences in rotifers [92]. 
Alertness [93] is regarded as another inducible defensive behaviour. Individuals with increased alertness show faster evasion responses [93] and increased swimming speed [94]. The latter seems to be an effective precapture defence $[58,94-96]$, for which copepods seem to be more optimized in comparison to cladocerans due to their elongated and streamlined body shape [91]. Nevertheless, predation trials, using a hydraulic apparatus, showed the effectiveness of evading or escaping the predator of fish-induced individuals of both cladocerans and copepods in comparison to their respective noninduced control [58]. Chang and Hanazato [95] hypothesized that the size of the prey positively correlates with the escape efficiency. They observed an increase in powerful strokes under predator exposure in C. reticulata and two Daphnia species (D. ambigua and D. pulex). These strokes allowed the prey to escape the predator by swimming faster and to tear themselves away from the predator even after being caught. The larger the preys' size, the higher was the escape efficiency. However, whether this is due to stronger strokes, or some other functional differences (e.g., gape-limitation of the predator), some of which are mentioned below, remains unclear.

Szulkin et al. [97] reported uniformity in swimming speed, hop and sink rate, and swimming angle induced by kairomones of fish and Chaoborus. The authors state that this might be an adaptation to reduce the detectability of individuals by the predator. As this similarity in movement was also exhibited in isolated individuals, the authors conclude that this response is based on individually perceived cues rather than a consequence of swarming behaviour. This uniformity in movements among individuals within a prey group may hamper the fixation on one particular prey item, thus confusing visually hunting predators.

Instead of increasing swimming speed, the exposure to kairomones can also trigger a decrease in activity, which may act as a pre- or a postcapture defence. Studies have shown a decrease in feeding and an increase in respiration rate in cladocerans exposed to predator cues $[23,98,99]$. While the latter might be a general physiological response to stress, the former may reduce the detectability and probability to encounter a predator (precapture), due to decreased activity in the upper water stratum. The dead-man-response has been reported as a postcapture defence [100]. This sudden motionlessness has been shown to be an effective survival technique applied by Bosmina against copepod predators [95].

In addition to behavioural defences that are directly linked to predator avoidance or evasion, mating behaviour is also influenced by predator presence. Male daphnids usually fight against other males, which occurs more often when sexually reproducing females are present [101]. Sexually reproducing females carry resting eggs instead of parthenogenetically produced eggs. When exposed to fish kairomones the males fight less amongst each other, and the mating rate increases. Furthermore, the males tend to attach more often to sexually reproducing females under predator exposure [101]. This increase in potentially successful mating may enhance sexual reproduction and thereby the adaptation to a changing environment.

A more offensive, inducible defensive behaviour has been observed by Sarma et al. [102]. When preyed upon by the worm Aeolosoma, cladocerans, especially Simocephalus serrulatus, exert defensive use of their postabdominal claw to prevent the worms from invading their brood chambers to feed on their eggs. This even led to fatal injuries of some worms. As the worms feed on algae as well, the authors hypothesized that this is not only a behavioural defence, since the putative prey may even feed on the disrupted tissue of the worms [102].

\subsection{Morphological Defences}

Many species of freshwater zooplankton have evolved inducible morphological defences, which act during various stages of the predation cycle, mainly postcontact $[9,103]$. These defensive structures generally evolved in response to specific predation regimes. They are bound to specific predator density schedules during the year in nature and have therefore also been described using the term cyclomorphosis (e.g., [12,18,104-106]). Inducible morphological defences show great variance among prey species and clones, according to the predatory regime of the prey-organism to which the prey adapted through previous encounters [107-109]. In the decades prior to the review by Lass and 
Spaak [17], many inducible morphological defences in response to fish were discovered in freshwater zooplankton. Some larger zooplankton species were found to reduce their body size but elongate their tail spine in response to visually hunting fish of a relatively small size [21,104,110]. In contrast, smaller zooplankton prey species do not show a general pattern of reduction in body size, but they enlarge or reshape body parts, like their antennulae, head and tail spines, or helmets, develop specific defensive structures such as neckteeth, and even change the appearance of their entire body to increase the survival rate in the presence of a specific invertebrate predator [15-19,104,110]. According to Dodson [104], these inducible morphological defences against invertebrate predators, might act via an "antilock and key mechanism". His theory suggests that induced morphological defences of zooplankton prey lead to a mismatch of the prey's morphology with the catching- or feeding-apparatus of invertebrate predators, and therefore to a higher escape and survival rate [12,104,111]. In general, inducible morphological defences should not be understood as one single trait that changes, but rather as a suit of armour that acts concertedly as a full body defence against predators. The defensive morphological alterations that act together as a protection are thought to have their individual justification at specific points during the predation cycle [9]. Various traits have already been taken into consideration, but many may still be undiscovered. Throughout the past 17 years, some previously unreported morphological defences were found and some already known defences were linked to specific predator traits, as pointed out below.

\subsubsection{Defences against Vertebrate Predators}

The hunting strategy of vertebrate predators of zooplankton, meaning mostly planktivorous fish, is visual foraging [24,112]. In contrast to invertebrate predators, fish do not depend on fine morphological chitinous catching structures, like parts of limbs, antennulae, and mandibles $[31,100,113,114]$. The general defensive response to fish is a decrease in body length, to reduce detectability, which we mainly refer to in the paragraph on life-history defences (e.g., [108,115-121]). This pattern was previously found for several Daphnia species $[21,122,123]$ and only recently for Bosmina longirostris and Eubosmina longispina [117]. A theoretical and more thorough explanation for this morphological developmental pattern in contact with fish is given by Stoks et al. [124]. The authors reconstructed the contribution of ancestral plasticity, constitutive evolution, and evolution of plasticity to the defensive shifts in body length of $D$. magna in response to changing fish predation. While the introduction of fish into a previously fish-free pond lead to the expression of a reduced body length in neonates and adults, a subsequent reduction in fish abundance caused the daphnids to still express this induced decrease of body length, albeit to a lower extent. Whereas mostly ancestral plasticity and the evolution of plasticity contributed to the defensive shift in body length at the first stock transition in the pond, all three components contributed to the defensive shift in body length at the second stock transition in the pond, indicating that morphological changes in response to fish predation can result from different combinations of nonevolutionary (phenotypic plasticity) and evolutionary (evolution of plasticity, constitutive evolution) processes. It is important to point out that these concepts of evolutionary and nonevolutionary processes underlying inducible defences are not restricted to the predator-prey combination of D. magna and fish or to morphological defences, but are applicable to inducible defences in general (e.g., [124-127]).

Only a few exceptions to the general pattern of a fish-induced reduction in prey body size to limit the visibility for the predator are documented. In these, the induced morphological enlargement of specific appendages was found to impair feeding by fish (e.g., [128-130]). One example of this is D. lumholtzi, which has been shown to develop large fornices and head and tail spines, protecting it against small $(20-25 \mathrm{~mm})$ fish $[116,128,129]$. D. lumholtzi's spines were found to get entangled in the mouth roof of these small fish, leading to the release of the prey [129]. On this basis, it was postulated that the protection through these spines can be connected with the potential gape-limitation of the predator's mouth and thus leads to a preference of smaller, less spined prey [129]. Engel et al. [131] demonstrated the advantage of longer head and tail spines through the comparison of two D. lumholtzi 
clones, one with longer, the other with shorter spines, against predatory fish. These clones were not exposed to the predator prior to the experiment, to rule out other, possibly hidden structural, morphological defences and a singularly test for the advantage of longer spines. The tested fish were large enough to feed on either morph, but still chose the less-spined clone significantly more often. Moreover, the previously suspected defensive advantage of induced spines across several life stages of D. lumholtzi, when encountering fish [132], could recently only be confirmed for adult $D$. lumholtzi [131]. These findings suggest that the advantage of the induced spine elongation takes effect at different points during the predation sequence for different life stages or sizes of prey. Therefore, it may not be purely effective at the point of ingestion (postcapture) but might operate as a precapture defence as well, making the predator less decisive on whether or not to attack a prey organism. The induced spine elongation in D. lumholtzi was found to vary among clones regarding the time until defence expression (compared with Tollrian [128]) [116]. This further suggests that clones may differ in reaction time or susceptibility to kairomones, the latter possibly depending on the origin of the clone and the predator regime the prey organism encountered there (compare with Boeing et al. [42]).

In addition to the defensive head and tail spines, defences on a larger scale or with a larger effect on the overall prey morphology can occur as a result of the exposure to a vertebrate predator. As mentioned in the paragraph on behavioural defences, Tollrian and Heibl [66] detected phenotypically plastic pigmentation in premature D. pulex in the presence of the fish Phoxinus phoxinus. They suggested that, because of their visual foraging strategy, fish might induce changes in pigmentation towards higher transparency. However, the response differed between species, according to the UV exposure to which they had to protectively adapt. A similar transparency in the presence of planktivorous fish was previously found in D. middendorffiana, which were more deeply pigmented in fish-free than in fish-containing ponds [110]. These discoveries might emphasize respective, specific habitat adaptations of Daphnia, as shown by Tollrian and Heibl [66], as trade-offs between UV-protection and visibility. For example, the increased transparency of a D. pulex clone indicates that it is either generally exposed to less direct UV-radiation or carries other protective mechanisms against it. In addition to that, the reduction in visibility as a defensive strategy was discussed regarding the eyespot size of zooplankton, which was found to be smaller in the presence of fish $[110,133]$.

\subsubsection{Defences against Invertebrate Predators}

While in the past, studies primarily focused on larger and more conspicuous defence structures against invertebrate predators, recent studies additionally addressed smaller and more unobtrusive morphological defences. For the investigation of inducible morphological defences of freshwater zooplankton in response to their invertebrate predators, some predators have been chosen repeatedly. Within this section, we arrange the reviewed studies according to the taxonomic order of the studied predator species and provide brief insights into the predator's feeding mechanisms.

Chaoborus larvae are the most studied invertebrate predators that induce defences in freshwater zooplankton. Chaoborus are ubiquitous and their larvae can be very abundant both in fish-free and fish-containing lakes and ponds, thereby representing an important trophic link between small zooplankton and higher trophic levels. The catching basket of the ambush predator Chaoborus limits the size range of its prey $[9,10,27,31,134]$. Chemical cues released by Chaoborus have been shown to enhance changes in body size in daphnids $[15,135,136]$ and to induce helmets, head spines and elongated tail spines. The most unique defence, that only Chaoborus has been shown to induce in several Daphnia species, is neckteeth in the dorsal region of the head with an enlarged neck-pedestal underneath (see Figure 1) [10,15,112,135,137-141]. All defensive traits differ in their reaction norm and effectiveness between different instars of Daphnia [140,142], predator instar, and predator species within the genus of Chaoborus $[136,140]$.

In particular, several studies investigating neckteeth were able to show large variation within this defensive trait between different Daphnia species and clones [27,41,107,143-145]. The induced neckteeth have been shown to differ in number, in their arrangement (line or rosette), and in the size of the 
neck-pedestal underneath them $[107,109,144-148]$. The defensive effect of the neckteeth is suspected to be a mechanical interference with the predator's fine mouthparts [31].

In addition, some experiments investigated the variation of this inducible defence throughout development. Laforsch and Tollrian [143] found that the developmental changes concerning the Chaoborus-induced neck-pedestal take place during the last embryonic stage in D. pulex. Adding to this, Imai et al. [148] showed the need for continuous induction of D. pulex through Chaoborus cues during embryonic development and even at an early postembryonic stage, for the maintenance of the neckteeth during the first three juvenile instars. The neckteeth reach their developmental maximum at the second or third juvenile instar, when they are at the preferred prey-size of Chaoborus [149]. After the third juvenile instar, the neckteeth decline and disappear. Another example for variance in this trait is D. longispina, which exhibits clonal differences in neckteeth development in response to Chaoborus across juvenile instars [145]. However, in the second juvenile instar, the neckteeth were most expressed in all tested $D$. longispina clones, and the neck-pedestal was also enlarged compared to the control. This emphasizes that an induced prey may show a defensive response according to its vulnerability at a certain life stage, with respect to the specific Chaoborus presence at that time. An example for the temporal alteration in defensive neckteeth production and the related competitive advantage under predation by $C$. crystallinus has been demonstrated for $D$. hrbaceki, which show a stronger tendency to form neckteeth compared to D. curvirostris [107].

In addition to the development of neckteeth, research revealed the induction of less predator-specific morphological defences in response to the predator Chaoborus, i.e., helmets and head and tail spines, which offer protection for various prey size classes in different Daphnia species against this invertebrate predator [150]. In C. flavicans-induced D. longispina the relative tail spine length was found to be longer than in induced $D$. pulex, which was attributed to the higher responsiveness of the smaller $D$. longispina to this invertebrate predator in comparison to the larger D. pulex [144]. The reason for this may be that an elongated tail spine could render D. longispina too large to fit into Chaoborus' catching basket. The same may be the case for Chaoborus-induced juvenile D. lumholtzi, which develop longer head and tail spines when encountering this predator [131]. Here, the defence may lead to a similar outcome (i.e., survival or escape) as under predation by fish, but the mode of operation of these defences differs. The longer spines could impede handling by Chaoborus since they might interfere with the catching basket, whereas in fish, the entire prey may get stuck at once.

The Chaoborus-related inducible morphological defences on a large scale have been shown to be accompanied by ultrastructural defences. Induced, inconspicuous changes to the carapace were found in Chaoborus-induced D. pulex and D. cucullata by using ultrasound microscopy [151]. In induced D. pulex, an increase in carapace hardness by $350 \%$ compared to the noninduced morph was observed, and in induced D. cucullata the carapace was twice as hard as in noninduced individuals. This study was also the first to reveal structural changes in the so-called pillars, which connect the inner and outer epidermal layers of the carapace in Daphnia. The study found an increase of pillar diameters in induced D. cucullata to about twice their original size. These structural alterations supposedly save costs for the defending prey organism through the production of a relatively small amount of material, in comparison to the investment necessary for larger defences. For D. pulex, this was further explored in a study by Kruppert et al. [30], where species-specific structural alterations in Chaoborus-induced $D$. pulex and Notonecta-induced D. longicephala were detected. While D. pulex developed a thicker procuticle with additional layers, induction of $D$. longicephala also lead to an increase in the number of layers, but without a change in total procuticle thickness. This study additionally tested for the contribution of the known defences to the carapace stiffness and found the induced ultrastructural carapace adjustments to be of more importance than the more prominent shape alterations. According to this study, with an increased number of layers in Daphnia's carapace, the possible orientations of chitin fibres, which make up a large part of each of these layers, increased. This resulted in an increased modulus of rupture, while the structural alterations may lead to an increased resistance to puncturing, either by Chaoborus mandibles or the Notonecta proboscis, during the predation process. The thicker 
procuticle with added layers in Chaoborus-induced D. pulex led to additional crush resistance and made up for the loss in carapace stiffness that is connected to the shape alterations, i.e., Chaoborus-induced neckteeth and neck-pedestal formation, in this species.

The loss in carapace stiffness, in connection with an induced morphological defence, i.e., crest formation, does not appear in Notonecta-induced D. longicephala. D. longicephala had previously been found to develop a unique, large crest, meaning a large extension of the dorsal side of the head region in a crescent-like form, and some even an elongated tail spine in reaction to backswimmers (Notonecta/Anisops/Buenoa) [111,152,153]. These predators are common in small ponds and lakes, where visual and mechanical cues originating from the prey organism trigger the predator's orientation and dash towards the prey $[112,113]$. The prey is grasped with its first two leg pairs, positioned, stung, liquefied, and the extraintestinally digested prey sucked out of its carapace [113]. The crest is thought to enhance the escape efficiency of the induced morph when under attack and there are various theories on its mode of action [111,152].

Inducible morphological defences in freshwater zooplankton have been further discovered in response to the tadpole shrimp Triops cancriformis. Several clones of the D. atkinsoni species complex were found to adapt to coexisting tadpole shrimp by forming a so called crown of thorns, an enormously wide, spined carapace extension in the form of a lobe on each side of their head proven to be effective against Triops predation (Figure 1) [154,155]. D. magna also coexisting with Triops in temporary waters induce a bulky morph, meaning an increased body width and body length, with an elongated tail spine [156]. Different Triops-induced D. magna clones were discovered to develop the "bulky" morph and an elongated tail spine together with an increase in the width of the shoulder shield [108]. However, the magnitude of the defensive traits varied among the three tested clones. Further, a gradual alternation of these defensive traits over the course of several instars of the prey was shown. This alteration secures the most effective protection of the organism for every developmental stage. D. magna's earlier instars seem to profit from an elongated tail spine, that is folded out after hatching as a start-up defence [143], while for adult daphnids the "bulkiness" seems to be the most effective combination of defensive traits. The benefit of the "bulkiness", enlarged tail spine, and wider shoulder shield throughout all of $D$. magna's life stages was proven via predation trials across size classes of predator and prey. Another extraordinary example for T. cancriformis-induced morphological defences was found in D. barbata by Herzog et al. [157]. This Daphnia species abandons its entire bilateral symmetry, forming a thoroughly twisted morph as a defence against the tadpole shrimp (Figure 1). In addition to these prominent defences, small-scale defences were also detected in Triopsand Notonecta-exposed D. barbata [28]. Spinules along the carapace margins were shown to increase in density, grow longer, and orientate sideways, compared to the control. While Triops induces small-scale defences, like spinules, this invertebrate predator also induces the expression of ultrastructural defences. D. magna exhibit an approximately five-times harder and two-times thicker cuticle with an increased diameter of the pillars in response to T. cancriformis [158]. Similar to the ultrastructural changes previously found in Chaoborus-exposed D. cucullata and D. pulex, these structural changes in D. magna lead to an increased resistance against the predator's, i.e., Triops', feeding mechanism $[29,158]$. The benefit of all the mentioned defences in contact with Triops might be explainable through the feeding mechanism of the tadpole shrimp, where the gnathobases of the anterior trunk limbs form a food grove in which prey is trapped, cage-like by the limbs, and moved towards the mandibles, where it is crushed $[108,114,158,159]$. Here, the interaction of induced defensive traits with fine chitinous predator structures may lead to either an increase in handling time, a tilt of structures, or an injury of the predator, in any case followed by a higher escape or release rate of the prey. This predator-prey interaction may confirm the proposed "antilock and key mechanism" of morphological defences [104]. 


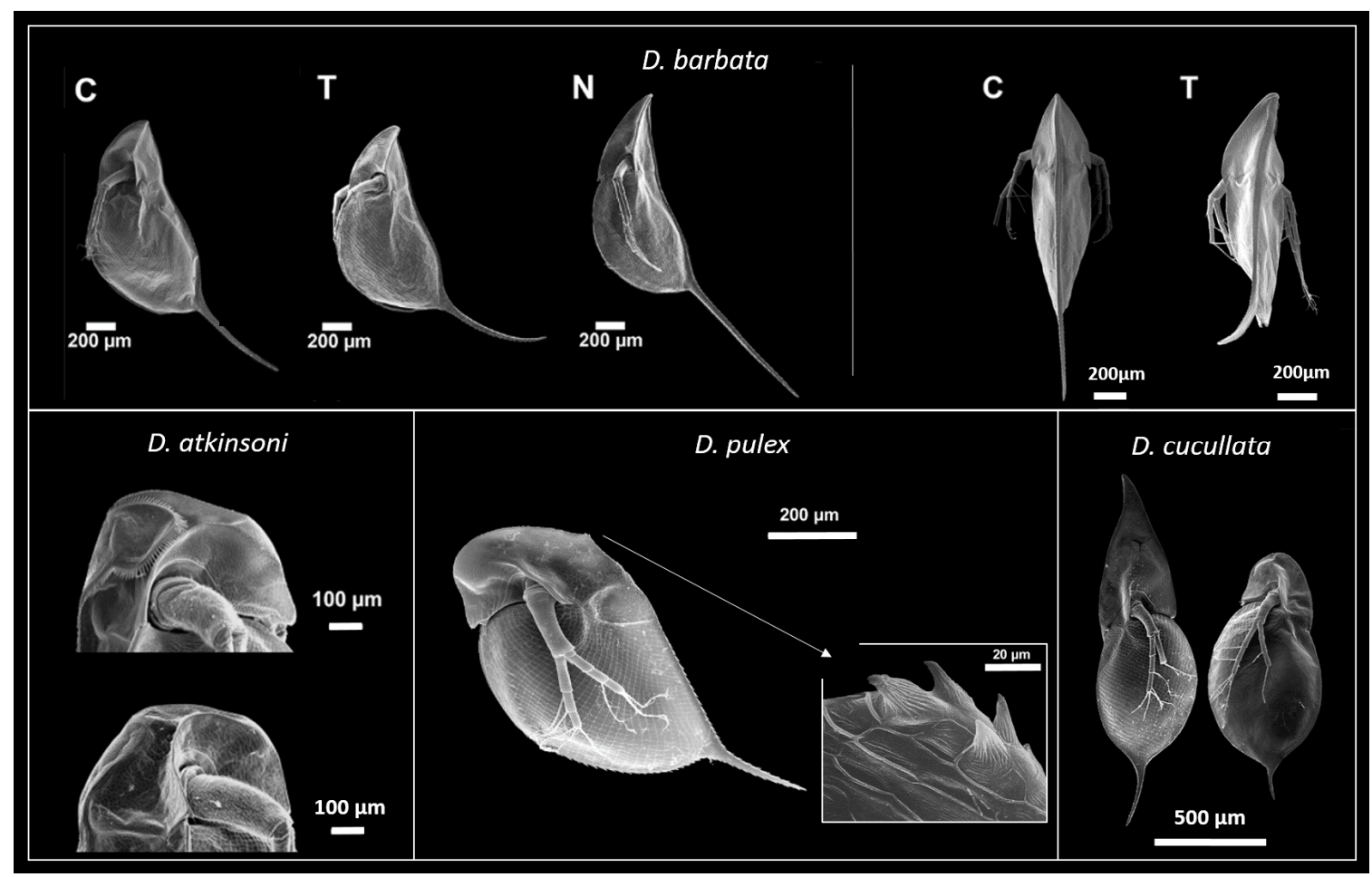

Figure 1. Inducible morphological defences in Daphnia. Top row: D. barbata expressing morphological defences in tail spine, helmet, and bilateral symmetry under exposure to Triops cancriformis $(\mathrm{T})$ and Notonecta glauca $(\mathrm{N})$ compared to the control (C) [28,158]. Bottom row: D. atkinsoni expressing a crown of thorns against T. cancriformis (top) compared to the control (bottom) [156]. D. pulex with neckteeth as defence against Chaoborus ([160], www.schweizerbart.de/journals/fal). D. cucullata with Chaoborus-induced helmet and tail spine (left) compared to the control (right).

Bythotrephes longimanus (Cladocera: Cercopagididae) is an invertebrate predator that has been shown to induce morphological changes in its prey's head morphology [161]. These changes include longer helmets in three clones of D. mendotae, comparable in degree to previously found helmets in response to Chaoborus [161]. The tactile predatory water flea Bythotrephes is known to prefer small sized Daphnia, which are caught and ripped apart during the predation sequence [162]. Therefore, an elongation of the head, in the form of a helmet, might potentially exclude $D$. mendotae from the preferred size spectrum and lead to handling difficulties for the predator.

Another prominent invertebrate predator of zooplankton is Leptodora kindtii, which can severely affect the populations dynamics of small zooplankton species, such as Bosmina and Eubosmina (Cladocera: Bosminidae), during its high abundances [163-165]. For Leptodora feeding on Eubosmina, the prey handling time was found to be correlated with its own body size and the species-specific antennule length of Eubosmina, emphasizing the importance of these elongated appendages for the prey's survival rate [163]. Also, certain Bosmina species were found to react specifically to Leptodora. This predator triggered B. fatalis to become dominant earlier in the year, compared to B. longirostris $[106,164,166]$. The induced longer mucro, which is comparable to a tail spine in Daphnia, in combination with a changed antennule shape and increased antennule length seem to provide B. fatalis with a defensive advantage, compared to B. longirostris, in the presence of Leptodora [164]. The induced changes in prey morphology may be related to Leptodora's trapping basket, which is formed by its pairs of legs [162,167]. An interference of the mucro or antennule with the legs, or an overall mismatch of the enlarged body with the size-limited handling ability of these legs may cause an increase in handling time and thus may increase the escape probability $[163,168]$.

A further invertebrate predator inducing elongated and shape-wise changed antennule in Eubosmina and Bosmina, similar to those expressed in response to Leptodora, is Mesocyclops (Cyclopoida: 
Cyclopidae) [169,170]. In fact, Bosmina and Eubosmina presumably build on a mixture of pre- and postcontact defences against invertebrate predators, including the protection of the ventral opening between the carapace-sides and the lateral antennae, the elongated antennule and mucro, as well as the consequential dead-man-response. Through this defence combination the mechanic stimulation of an invertebrate predator is behaviourally avoided while, in case of a contact, the next lines of defence, i.e., the induced morphological traits, ensure an increased handling time, similar to neckteeth in Chaoborus (e.g., $[104,171,172])$.

Further inducible morphological defences of freshwater zooplankton can be found in response to the freshwater jellyfish Craspedacusta sowerbii. B. longirostris was found to elongate its mucro and antennule in response to this predator [168]. The hunting strategy of Craspedacusta is dependent on the water flow that carries prey towards its floating tentacles [168]. The author discusses the need for further experiments to show the exact mode of action in this freshwater jellyfish and its prey.

The rotifer Asplanchna (Ploima: Asplanchnidae) was one of the first predators shown to induce morphological defences in its zooplankton prey [173,174]. Asplanchna was found to induce spine elongation in the smaller rotifer Brachionus calyciflorus (Ploima: Brachionidae). The work with this predator genus was continued in several experiments, which tested marine, brackish, and freshwater zooplankton for inducible morphological defences. An elongation of multiple spines along the prey's body was found for several Asplanchna-prey (Keratella, Brachionus, Plationus) combinations (e.g., [40,92,175-179]). Further, the strength of this induction seems to be related to Asplanchna density [180]. Nandini et al. [177] were able to show the important contribution of the spine length in differently spined, yet noninduced Brachionus species, as well as the prey density for limiting the catching and consumption by Asplanchna sieboldi. This might be similar for induced Brachionus but is still to be tested. Asplanchna were shown to selectively prey on less spined morphs, if these are available, making the changed spine morphology in prey organisms beneficial by means of gape-limitation, since Asplanchna feeds on its prey by sucking it up entirely $[19,177]$. While morphological defences in other groups of zooplankton can vary over developmental stages, the morphology of rotifers is determined at birth, and could therefore be understood as a maternal-induced defence [19].

\subsection{Life-History Defences}

Changes in life-history, comprising, e.g., size at first reproduction (SFR), age of maturation, number and size of offspring, production of resting eggs, and longevity, are well-known inducible defences in many zooplankton species (e.g., [99,120,181-184]). Thus, functionally oriented response patterns, such as a change in SFR, are often combined with other (e.g., morphological) predator-induced defences. Given that most invertebrate predators are gape-limited, freshwater zooplankton prey organisms of a matching size range will increase their SFR by increased growth and/or formation of morphological structures (e.g., helmets or elongated spines) potentially at the cost of reduced reproduction (e.g., delayed maturity or less offspring). In contrast, most freshwater zooplankton will reduce their SFR and visibility but increase their resource allocation into reproduction in response to predation by visually hunting vertebrate predators. These patterns are often passed on to the next generation, producing bigger or smaller offspring, respectively $[185,186]$.

Some studies report no or varying predator-induced life-history changes in different Daphnia species, or even clones of single species. Some literature reports are contradictory. For example, some species have been found to increase their SFR in one study, but to reduce it in another one in response to the same predators $[4,148,187-190]$. Such contradictory results may derive from factors influencing the response that were not considered in the respective studies, such as the origin and the developmental stage of the prey, or the light intensity.

There is evidence that a multitude of predator-induced response patterns depend on the prey's origin (e.g., temporary pond vs. lake), and on the type of predators the prey has encountered previously $[42,191]$. D. pulex for example, responded stronger to fish or Chaoborus when the clone that was used derived from a location that was inhabited by the respective predator. In other cases, 
the prey responded in a pattern they usually exhibit against another predator, even though it was maladaptive or they showed indefinite, mixed responses [42]. On the other hand, invasive predators are also able to induce life-history defences that follow the predicted patterns previously mentioned. In a 12 year long-term study, life-history changes in zooplankton were related to the invasion of a new fish species [117] that had been introduced in addition to other native fish species. During this study, the zooplankton community (mainly Daphnia spp. and Bosmina spp.) generally reduced their SFR and increased their clutch sizes, while the largest species (D. longispina) was eliminated. This again may hint to a potential similarity of predator cues (e.g., one fish cue). However, it is still unclear to what extent the predatory history or prey's origin affect the induction of defences in general.

Furthermore, the type of defence or the defence strength can differ, depending on the developmental stage or instar at which the organism was exposed to the predator cues [192,193]. The most pronounced life-history change (i.e., earlier maturation) was achieved by exposing fourth instar daphnids to fish cues. Additionally, when the mothers were already exposed to fish, the reaction norm of their offspring was found to be much broader, which has been discussed as an adaptation to an unpredictable environment for the offspring [193].

As reported for behavioural defences, life-history changes in Daphnia are also affected by light $[119,120,189,194]$. Life-history changes were inversely coupled to light intensity (the SFR was reduced when exposed to intense light), but there was no induction in the dark $[119,120]$. Resting egg production in Daphnia was found to increase in response to fish exposure and to be suppressed in the dark as well, and thus has been discussed as a strategy to escape fish predation [189]. Both reactions (reduced SFR and suppression of resting egg production) may provide an advantage by decreasing the visibility to fish, which would be obsolete in the dark.

Slusarczyk and Rybicka [188] also found reduced resting egg production in Daphnia that were simultaneously exposed to fish kairomones and high temperatures, but not in Daphnia that were solely exposed to high temperatures in the absence of kairomones. The authors discuss that Daphnia used the shorter developmental times at increased temperatures, and thus increased the number of offspring to counteract population losses by predation. Under exposure to fish kairomones at low temperatures they increased the production of resting eggs to escape times with high predation pressure and slower developmental rates. In D. galeata and D. similis, La et al. [121] additionally found the egg type (asexually or sexually produced) determined the inducibility of defensive morphological changes in hatchlings. While they found defences to be regularly inducible in hatchlings of asexually produced eggs, defences in sexually produced eggs (i.e., resting eggs) were constitutively expressed and an amplification of the defence was not inducible. This might be an adaptation to a hatching phase of the resting eggs, during which predation pressure may be predictable [121]. On the other hand, this might also be an adaptation to an unpredictable future into which the offspring is released, where it may need high protection directly after hatching.

Not only external factors can influence the expression of inducible defences. Wolinska et al. [195] revealed that the strength of the induced defence is a function of the intrinsic values of defence traits in Daphnia. That means a small individual is supposed to respond more strongly (with an even stronger increase in growth) to an invertebrate predator than a large individual.

However, especially with regard to life-history changes, two contrasting hypotheses are discussed: on the one hand adaptations (i.e., reduced SFR and changes in reproduction) may be responses to size selection as a defence against specific predators. In contrast to this, it has been discussed whether adaptations are trade-offs due to changed activity and subsequently reduced food intake [196]. Following the latter hypothesis, size-selective predation by fish should lead to reduced SFR, which then would lead to delayed maturity, because maturation would be coupled to growth. In that case, a reduction in size at maturity under predation would merely be the consequence of an increased resource allocation, from somatic investment into reproduction, rather than a purposive defence that aims to reduce visibility and increase the offspring number to overcome predation losses. On the other hand (still following the latter hypothesis), negative-size-selective predation (i.e., by invertebrates) 
would lead to an increased SFR and therefore to an earlier maturation. This issue has been summarized by Beckerman et al. [196]. The authors tested both theories and found that Daphnia matured earlier, even though their growth rate slowed down, when exposed to fish, while SFR was increased, but maturity was delayed under invertebrate predation $[99,196]$. This shows that somatic growth and individual development (i.e., maturing) can be decoupled by predator exposure $[99,196]$ and therefore can be seen as a purposive defence mechanism. Nevertheless, this mechanism is still affected by food intake. Riessen [197] concluded from his experiments with D. pulex and Chaoborus that a delay in reproduction is not a real trade-off with increased growth, but that there is a strong linkage between those traits, even though the mechanism is still unclear. Additionally, Klintworth and Von Elert [198] showed that food intake and resource allocation have an impact on the expression of multiple defences, including SFR. However, changes in life history, such as SFR, cannot be fully explained by food availability [196,199]. Therefore, the ultimate factor for life-history changes is the individual predation risk, rendering this inducible defence a purposive response to size selective predation.

\subsection{Conceptual Approaches for Multipredator Studies}

In a natural context, defences rarely evolve in response to a single predator. In freshwater habitats, multiple predators co-occur and therefore exert their selective pressure simultaneously $[12,134]$. The induced defences are inferred to be the optimum defensive trade-off for a prey species encountering a respective predation regime at a specific time. Previous studies found the development of defences to be oriented towards the dominant predator at a particular time, with respect to, e.g., abundance or prey-preference, or towards an intermediate compromise $[28,200]$. This dominant predator may vary seasonally, according to its respective life cycle [12].

When studies try to address inducible defences of freshwater zooplankton in a natural multipredator situation, there are two basic approaches. In some cases, a sampling of predators and prey in nature is the starting point, which is followed by comparing the data obtained in this way with that from follow-up laboratory studies with the obtained organisms (e.g., [201]). Other studies start with a number of laboratory experiments with various potentially co-occurring predators as well as their prey and compare these results to data they find in the field, in later studies (e.g., [131,176,202]). On one hand, in concepts that start off with sampling in the field, it is difficult to distinguish individual influences of predators on different characteristics of inducible defences. This approach is limited at its basis by the sampling, meaning the method, spot (biodiversity, characteristics of the specific habitat), and seasonality (including weather). On the other hand, in the concept where laboratory studies are executed first, the design of these laboratory studies is crucial. A multitude of aspects has to be considered to clearly separate influences of predators on different induced defence characteristics in experiments. Therefore, a basic framework is needed to distinguish the predator-influence on certain aspects of the induced defence. In 2003, Relyea reviewed multipredator-prey studies on the induction of defences, most of which were conducted in aquatic systems. He noted that in order to disentangle influences of various predators in multipredator studies, (a) the prey consumption should be managed in a controlled manner, (b) the number of observed traits should generally be high, (c) there should be a variation in the predator combination, and (d) there should be some distinction between changes in total predator abundance and changes in predator regime. The studies conducted so far generally do not meet these requirements, making a clear interpretation of the individual predator contribution to an induced morph very difficult.

In a different approach, to better understand the quality of the selection pressure for the induction of defences in response to multiple predators, Herzog and Laforsch [28] introduced the "concept of modality". The three categories, functionally equivalent, functionally inverse, and functionally diverse, which can be further distinguished, were introduced to differentiate the pattern in which two different predators can impact the expression of a defence in a prey organism. The induction through two invertebrate predators (T. cancriformis and N. glauca) that exert very different qualities of selection pressure led to the development of two very different appearances of the same induced 
traits in D. barbata (Figure 1). These served as distinct defences when encountering the two predators separately. The thorough use of either of the introduced concepts would open new paths for the explanation of inducible defences of freshwater zooplankton in a multipredator context.

\section{Costs for Inducible Defence}

Although a wide spectrum of inducible defensive traits and a huge variety of factors modulating these defences have been discovered, our knowledge about the costs that accompany an inducible defence is still scarce and inconclusive. Costs of inducible defences can be assigned to five categories: plasticity costs, self-damaging costs, allocation costs, opportunity costs, and environmental costs [7]. However, as we do not cover genetics and molecular contexts in this review, we will not go into plasticity costs that include costs for maintaining the ability to be plastic, as well as maintaining sensory structures to detect predators. Further, to our knowledge, there are no reports about self-damaging costs in freshwater zooplankton.

Food availability plays a role in the expression of induced defences in freshwater zooplankton, indicating the existence of allocation costs. They are represented by direct metabolic demands, e.g., due to increased respiration rate $[23,203]$, or direct energy and material costs for forming and maintaining defences, such as morphological structures or increased reproduction (e.g., [99,194-196]). Several studies already reported increasing demands of nutrients with increasing predation risk, or reduced defence expression under nutritional constraints [99,204-208]. However, it is difficult to estimate allocation costs with definite numbers, as it is not easy to determine whether the resources are allocated into a defence, like PUFAs that are needed for increased reproduction [75], or whether constraints are caused by other factors as well, such as the previously mentioned increase in PUFA demand due to low temperatures. Furthermore, prey species might compensate for nutritional losses by changing their activity or feeding modes [209].

Opportunity costs comprise the loss of benefits that the prey would have experienced if it had not developed defences, such as reduced growth and fecundity, or loss of competitive ability. They can also be seen as long-term allocation costs [7]. These costs might even be passed on to future generations that might consequentially suffer from the predation pressure to which their parents were exposed. The abandonment of DVM under low food conditions may indicate such opportunity costs $[49,59,210]$. Under generally limiting food concentrations, staying in upper water layers that provide higher food concentrations than deep strata seems to outweigh the benefits of DVM. A loss of the competitive ability in response to fish-induced DVM was shown by Dawidowicz and Wielanier [81]. In their study, Daphnia performed DVM, whereas Ceriodaphnia stayed in upper water layers. As a consequence, Daphnia suffered from reduced population growth because of the costs associated with DVM, while Ceriodaphnia increased their population growth, which the authors attributed to the increased resource availability for Ceriodaphnia after Daphnia vanished from surface waters. Food intake is also decreased due to lower feeding rates, or lower activity to reduce the encounter probability $[23,98,99]$. Therefore, this might also be counted as an opportunity cost as well. The same might be true for decreased reproduction and increased developmental time due to lower temperatures $[60,67,79]$. However, the classification of food availability as well as temperature into certain categories of costs may be context dependent, as they are generally considered as environmental costs [7]. Nevertheless, a decrease in reproduction is not necessarily detrimental. In combination with increased somatic growth, it can indirectly increase the overall population growth under predation due to decreased mortality by predation [182], indicating clear trade-offs. Reduced longevity might be another cost linked to defence induction that indirectly influences population growth. However, an acceleration of senescence, which might act as a long-term cost, could not been detected in a study with D. pulex and D. magna [211] and even an increase in longevity was detected in D. similis and Moina macrocopa [184].

The best studied and most reported costs are environmental costs. They are occasional costs that are caused by the surrounding environment. An increased visibility due to pigmentation against UV-radiation is one example for environmental costs $[60,65,66,79]$. Another example is that the defence 
against one predator may render the prey more vulnerable to another predator (e.g., $[42,88])$, such as the optimal size against invertebrate predators (large) and vertebrate predators (small) [185]. However, there are defences that act against several predators at the same time $[28,42,54,202]$, like the inducible defences in D. barbata against $N$. glauca, which also provides protection against T. cancriformis [28]. Also, the life stage of the predator might provoke environmental costs, depending on the preferred prey size of the predator's instar, age, or size $[26,82,84,199]$. With fish as the predominant predator, a reduction in prey size may be beneficial against large fish, but in turn might be maladaptive against smaller, young fish of the same species, as those may prefer smaller prey. Even though a reduction in size in the presence of young fish can be considered a maladaptation, Hülsmann et al. [199] found a reduction in prey size under high food availability. The authors discuss that this is an unrealistic event in nature, as young perch occur in late spring, where food levels are relatively low, due to the clear water phase.

Additionally, not only the vulnerability of the prey to predators can be increased, but also the vulnerability to parasites might be affected under predation [212,213], which would be counted as an environmental cost as well. Vice versa, the parasites may also affect the ability of the prey to defend themselves against predators [214].

For a thorough understanding of the costs that are associated with inducible defences in freshwater zooplankton, it is insufficient to investigate only one stressor at a time. Hammill et al. [215] stated that knowledge about long-term costs is necessary to understand the evolution of inducible defences. Especially, multipredator- and multistressor-systems should be investigated more in future research, as prey is rarely exposed to only one predator and stressor at a time under natural conditions. Moreover, many costs might be diffused or hidden in experiments by sufficient food supply, or other environmental conditions that cover potential costs. Further to this, costs are difficult to quantify (see also Riessen [197] and Tollrian and Dodson [112]). They may be measured as a relative reduction in growth rate, or reproduction, or might be estimated as an increased resource demand. Depending on the considered defence, this might not be possible, especially when more elusive costs need to be considered (that might not have been found so far), such as evolutionary costs.

While inducible defences have thus far been thought to be connected with costs, they might instead provide an evolutionary benefit. In contrast, a constitutive defence may have an evolutionary cost. A constitutive defence is more predictable for the predator, allowing it to adapt more easily to a prey's defence. Thus, the expression of an inducible defence by the prey, with high variability and an occurrence only under certain circumstances (e.g., after passing a threshold of predation pressure), would prevent or slow down the adaptation process of the predator. Therefore, the direct costs associated with expressing an inducible defence might actually be less relevant than the costs associated with having a constitutive defence, rendering an inducible defence beneficial rather than costly in an evolutionary context.

\section{Defence-Inducing Cues}

The characterization of defence-inducing chemical cues has been a major challenge in the last few decades. The following reasons for this have been discussed previously [216,217]: Defences might be induced by more than just one chemical compound, which complicates the identification and testing of putative kairomones. Furthermore, chemical cues might be potent already at picomolar concentrations, making their proof and quantification in nature challenging. Developing and conducting suitable bioassays, to test the substances in question, is another prerequisite for characterizing chemical cues. Since the review by Lass and Spaak [17], tremendous effort has been invested, especially for cladocerans, in identifying and describing chemical and physical cues that trigger inducible defences [14,194,218-224]. Nevertheless, the chemical structures of kairomones as well as their mode of action are still unknown in most cases.

In general, there are some suspected substances for kairomones that are commonly used for intraas well as interspecific information transfer. Invertebrates often release peptides or peptide-based substances $[14,225,226]$, while vertebrates seem to release bile salts that induce a defence in prey 
species [227,228]. Aliphatic sulphates released from Daphnia have been found to induce defences in algae [229]. The chemical structure of these substances can be manifold $[225,228]$. Moreover, they can be modified (e.g., [14]), producing even further complexity in information transfer. In general, there seems to be a wide array of substances that are perceived as predator cues by prey. Furthermore, their putative combination to cocktails adds to their complexity and putative specificity as kairomones, as pointed out, for example, in the reviews of Parejko and Dodson [230] and Pohnert et al. [216]. Therefore, it is likely that those (combined) substances can be largely species-specific and prey should have evolved the ability to distinguish between predator species, or at least between several predator types (such as invertebrates vs. vertebrates), allowing the prey to display defences that are specifically effective against the most relevant predator at a given time and space.

However, the controversy, pointed out by Lass and Spaak [17], about whether there is one fish factor, or whether prey are able to distinguish between different fish species, still continues. Even though there is evidence that prey organisms are able to react differently to some fish species [222], there are contradictory studies that still find no difference in defence induction when Daphnia were exposed to different fish species (e.g., [220,231]). As pointed out in the former sections, the response to fish predators is usually expressed in accordance with a general pattern, i.e., reduced size and increased reproduction (e.g., [203,210,232]). Thus, the reaction norm may depend on kairomone concentration $[220,221]$, which would not only explain the differences in the reaction norm between fish species (bigger fish might produce more kairomone) but also the response differences between small juvenile and fully-grown adult fish [199]. A potential kairomone concentration dependency of the induction of defences could be shown in invertebrates with Triops in one study [108] and also over various other taxa by demonstrating that the predator as well as the prey density can modulate the strength of defence induction [233].

Recently, Hahn et al. $[227,234]$ identified and described a fish factor that induces diel vertical migration in Daphnia as $5^{\prime} \alpha$-cyprinolsulfate, a bile salt excreted by carp (Cyprinus carpio) and roach (Rutilus rutilus) during digestion. They also stressed that this bile salt may be a general kairomone in cyprinid fish, although it also seems to exist in smaller concentrations in rainbow trout (Oncorhynchus mykiss). This implies that there are different bile salts or substances with a similar structure that may act as kairomones and derive from other fish orders [227,234]. Bile salts are a common by-product of the digestion process in all vertebrates, thus explaining why predators are not able to control production and excretion of these substances [228]. Nevertheless, there probably is more than one chemical cue exuded by fish. In 2006, Beklioglu et al. [219] found mucus-dwelling bacteria to contribute to the production of kairomones, which had previously already been suggested by Ringelberg and Van Gool [235]. Fish incubation water usually induces distinct migratory behaviour in Daphnia. Water containing only fish mucus resulted only in intermediate response strength in D. pulex as compared to incubation water containing fish. Incubation water produced with antibiotics-treated fish also resulted in intermediate response strength. Such findings support the idea of a cocktail of chemical compounds that interact to induce different, more or less predator-specific, defences. However, bacteria may also be responsible for a relatively short half-life of kairomones, due to degradation [205].

Recently, a combination of different substances released by an invertebrate predator was found to induce defences in Daphnia. The kairomone of the phantom midge larvae (Chaoborus) induces neckteeth in D. pulex. Weiss et al. [14] reported that the Chaoborus kairomone consists of fatty acids conjugated with the amino group of glutamine via the $\mathrm{N}$-terminus. These compounds are thought to be a by-product of the digestion process of Chaoborus, similar to bile salts in fish. Several combinations of fatty acids conjugated with glutamine were found in the extract, each by itself inducing a response in D. pulex. They showed that fatty acids with a chain length of 14 carbon atoms or more have a higher potential of inducing neckteeth in D. pulex. The naturally-found fatty acids $\alpha$-linolenic acid and linoleic acid seem to be the most potent conjugates for the induction of defences. Likewise, glutamine can be exchanged by glycine or alanine; the latter lowering the actual defence expression. These findings suggest that kairomones released by predatory invertebrates consist of a mixture of compounds, 
rather than single substances. In addition, the concentration of each compound may be important for the modulation of the defence against specific predators. However, this remains unclear until more detailed studies on the single compounds of putative chemical-cue cocktails have been carried out.

Beside kairomones, other cues are used by prey to assess the acute predation risk. Several studies have investigated chemical cues released by harmed or killed prey: so-called alarm cues. Extracts gained from injured or macerated daphnids can also induce defences in Daphnia, similar to predator kairomones, though less pronounced $[22,23,194,236]$. Cues generated through feeding on conspecifics seem to exert stronger responses than cues derived from feeding on other prey species, or from a Daphnia-free diet [22]. Thus, Mitchell et al. [237] proposed a distinction between predator cues that are directly originating from the predator itself, dietary cues that are a result or a by-product of the digestion process of the predator, and alarm cues originating from injured prey. These different classes of cues are often difficult to separate experimentally. Therefore, distinct prey responses to either one or the other kind of cue are, for now, not detectable as long as we are not able to synthesize pure kairomones and/or alarm cues, respectively. From an ecological point of view, this might not be relevant, as those cues are unlikely to occur singularly under natural conditions.

More than just chemical cues can induce defences. There is evidence that zooplankton also use physical stimuli for predation risk assessment. It has been demonstrated that small scale turbulence can induce defences in D. cucullata and in B. longirostris as well as in (marine) copepods $[150,223,238,239]$. The induction through turbulence is presumably not triggered by wind or storm events, but is thought to result from the predator's movement while swimming or hunting [223]. Visual cues can also be important for the recognition of predators. A behavioural response in mysids has been triggered by a combination of chemical and visual stimuli, but not by one stimulus alone [89]. It is thought that these cues act synergistically for the prey's assessment of whether there is an actual predation risk, and to save costs if predators are present in the system, indicated by chemical cues, but are not in physical proximity [223].

Lass and Spaak [17] have pointed out that the induction scenario becomes even more convoluted in the context of a complex chemical environment with multiple stressors. In addition to the abiotic and biotic factors pointed out before, many recent studies have investigated interactions between predator cues and anthropogenic substances, such as drugs, heavy metals, and chemical additives (e.g., flame retardants, plasticisers, or stabilisers). Indeed, many substances have been found that are able to interfere with, counteract, or inhibit the induction of a defence (e.g., [236,240-247]). Reasons for this influence on inducible defences in zooplankton are poorly understood and presumably manifold. They may also involve the inhibition of receptors or molecular pathways, or may provoke reversed responses that counteract defence development. The transfer of information may also be diminished through the adsorbance of kairomones to surfaces, e.g., to plastic waste, as was shown using high-density polyethylene (HDPE) and polyethylene terephthalate (PET). When the respective plastic particles were present in the water, they significantly reduced the defence strength in $D$. longicephala against N. glauca [248]. This might be important, as plastic vessels should be avoided when kairomones are stored and/or applied. However, we will not go into detail of those eco-toxicological aspects here, as they are not the focus of this review.

\section{Conclusions and Future Perspectives}

Although huge efforts have been invested into research on inducible defences within the last century, hitherto unknown inducible defences are still being discovered, especially regarding morphological defences. Here, striking discoveries of previously unknown defences include the crown of thorns, the thickening of the carapace, and the loss of the bilateral symmetry [157]. The exact mode of action for each of the above explained morphological defences is still not known, and it seems that we have only scratched the surface of the effects that combinations of multiple factors may evoke on inducible defences [28,202]. Those factors comprise abiotic (i.e., light, UV-radiation, oxygen, temperature, $\mathrm{pCO}_{2}$, or water chemistry), biotic (i.e., bacterial degradation and/or facilitation, 
predator species, predator age or instar, predator and prey density, food availability, and the predatory history), and anthropogenic factors (i.e., drugs, heavy metals, and xenobiotics), which may even interact in their effects on defence induction. All the research (see Table A1) conducted in the past few decades highlights the complexity of inducible defences in freshwater zooplankton, and also reveals significant gaps in knowledge, especially regarding the specific mechanism modulating defence induction and their significance for ecosystem processes. Thus, we need to keep up the recent trend for more multifaceted experiments, such as the investigation of stressor interactions. Furthermore, multipredator studies are required, considering the above mentioned recommendations of Relyea [249]. Following these recommendations may facilitate the interpretation of experimental data and may allow for the creation of a more holistic understanding of inducible defences against multiple predators.

With the growing knowledge in this research field, we are forced to increase the complexity of our experiments to understand interaction effects and how they affect the dynamics of predator-prey interactions. For this, it will be necessary to combine laboratory experiments with field observations and to test whether findings and conclusions drawn from laboratory experiments can be found in the field. Additionally, new findings on kairomones will help to work with and to standardize the application of kairomones and may allow for the quantification of the kairomones in the field in future studies. We have just opened an exciting new chapter in the field of predator-prey interactions, in which the recent work on freshwater zooplankton has revealed new avenues that now need to be explored in future research.

Author Contributions: Writing—original draft preparation, P.D. and M.K.; writing—review and editing, P.D., M.K., D.M.-C., and C.L.; visualization, P.D., M.K., and C.L. All authors have read and agreed to the published version of the manuscript.

Funding: This research received no external funding.

Acknowledgments: We would like to thank our colleagues at the department of animal ecology I, University of Bayreuth, for proofreading the manuscript. We would also like to thank two anonymous reviewers for their valuable comments, which led to a significant improvement of the manuscript's quality. Moreover, we thank Schweizerbart Science Publishers for granting us permission for reusing a picture of a previous publication in Archiv für Hydrobiologie. This publication was funded by the German Research Foundation (DFG) and the University of Bayreuth in the funding program Open Access Publishing.

Conflicts of Interest: The authors declare no conflict of interest. 


\section{Appendix A}

Table A1. Collection of studies completed since 2003 on inducible defences in zooplankton, each listed with their specific characteristics. Prey and predator species are specified to the level mentioned in the respective study. In cases of uncertainty, whether a single or a set of clones were used or where no clonal lineages were applicable, n.a. is quoted.

\begin{tabular}{|c|c|c|c|c|c|c|c|c|c|}
\hline Zooplankton Species & Predator & Behaviour & Morphology & Life-History & Single Clone & Multiple Clones & Field Study & Laboratory Study & Source \\
\hline Argyrodiaptomus falcifer & $\begin{array}{c}\text { Cnesterodon } \\
\text { decemmaculatus }\end{array}$ & $\mathrm{x}$ & & & n.a. & n.a. & & $\mathrm{x}$ & [58] \\
\hline Bestiolina similis & Amphiprion ocellaris & $\mathrm{x}$ & & & n.a. & n.a. & & $\mathrm{x}$ & [239] \\
\hline Bosmina coregoni & Fish & $\mathrm{x}$ & & & n.a. & n.a. & $\mathrm{x}$ & & [80] \\
\hline \multirow{9}{*}{ Bosmina longirostris } & Acanthocyclops verinalis & & $\mathrm{x}$ & & & $\mathrm{x}$ & & $\mathrm{x}$ & [238] \\
\hline & Copepoda & & $\mathrm{x}$ & $\mathrm{x}$ & n.a. & n.a. & $\mathrm{x}$ & & [106] \\
\hline & Coregonus alba & & $\mathrm{x}$ & $\mathrm{x}$ & n.a. & n.a. & $\mathrm{x}$ & & [117] \\
\hline & Craspedacusta sowerbii & & $\mathrm{x}$ & $\mathrm{x}$ & n.a. & n.a. & $\mathrm{x}$ & & [168] \\
\hline & Fish & $\mathrm{x}$ & & & n.a. & n.a. & $\mathrm{x}$ & & [80] \\
\hline & \multirow{2}{*}{ Leptodora kindtii } & & $\mathrm{x}$ & $\mathrm{x}$ & n.a. & n.a. & & $\mathrm{x}$ & [164] \\
\hline & & & $\mathrm{x}$ & $\mathrm{x}$ & n.a. & n.a. & $\mathrm{x}$ & & {$[13,106]$} \\
\hline & Mesocyclops leuckarti & $\mathrm{x}$ & $\mathrm{x}$ & & $\mathrm{x}$ & & & $\mathrm{x}$ & [95] \\
\hline & Mesocyclops sp. & & $\mathrm{x}$ & & $\mathrm{x}$ & & & $\mathrm{x}$ & [170] \\
\hline \multirow{5}{*}{ Bosmina fatalis } & Copepoda & & $\mathrm{x}$ & $\mathrm{x}$ & n.a. & n.a. & $\mathrm{x}$ & & [106] \\
\hline & \multirow{2}{*}{ Leptodora kindtii } & & $\mathrm{x}$ & $\mathrm{x}$ & n.a. & n.a. & & $\mathrm{x}$ & [164] \\
\hline & & & $\mathrm{x}$ & $\mathrm{x}$ & n.a. & n.a. & $\mathrm{x}$ & & {$[13,106]$} \\
\hline & Mesocyclops leuckarti & $\mathrm{x}$ & $\mathrm{x}$ & & $\mathrm{x}$ & & & $\mathrm{x}$ & [95] \\
\hline & Mesocyclops sp. & & $\mathrm{x}$ & & $\mathrm{x}$ & & & $\mathrm{x}$ & [170] \\
\hline \multirow{2}{*}{ Bosmina sp. } & Fish & $\mathrm{x}$ & & & n.a. & n.a. & $\mathrm{x}$ & & [54] \\
\hline & Mochlonyx fuliginosus & $\mathrm{x}$ & & & n.a. & n.a. & $\mathrm{x}$ & & [54] \\
\hline \multirow{5}{*}{ Brachionus calyciflorus } & \multirow{2}{*}{ Asplanchna brightwelli } & & $\mathrm{x}$ & & $\mathrm{x}$ & & & $\mathrm{x}$ & [179] \\
\hline & & & $\mathrm{x}$ & $\mathrm{x}$ & n.a. & n.a. & & $\mathrm{x}$ & [178] \\
\hline & Asplanchna sieboldi & & $\mathrm{x}$ & & $\mathrm{x}$ & & & $\mathrm{x}$ & [177] \\
\hline & Asplanchna sp. & & $\mathrm{x}$ & & $\mathrm{x}$ & & & $\mathrm{x}$ & [233] \\
\hline & Daphnia pulex & & $\mathrm{x}$ & & $\mathrm{x}$ & & & $\mathrm{x}$ & [179] \\
\hline
\end{tabular}


Table A1. Cont.

\begin{tabular}{|c|c|c|c|c|c|c|c|c|c|}
\hline Zooplankton Species & Predator & Behaviour & Morphology & Life-History & Single Clone & Multiple Clones & Field Study & Laboratory Study & Source \\
\hline Brachionus havaensis & Asplanchna sieboldi & & $\mathrm{x}$ & & $\mathrm{x}$ & & & $\mathrm{x}$ & {$[177]$} \\
\hline Brachionus macracanthus & Asplanchna sieboldi & & $\mathrm{x}$ & & $\mathrm{x}$ & & & $\mathrm{x}$ & {$[177]$} \\
\hline Brachionus patulus & Asplanchna sieboldi & & $\mathrm{x}$ & & $\mathrm{x}$ & & & $\mathrm{x}$ & [177] \\
\hline Brachionus rubens & Asplanchna sieboldi & & $\mathrm{x}$ & & $\mathrm{x}$ & & & $\mathrm{x}$ & {$[177]$} \\
\hline \multirow{2}{*}{ Brachionus variabilis } & Asplanchna girodi & $\mathrm{x}$ & $\mathrm{x}$ & & $\mathrm{x}$ & & & $\mathrm{x}$ & [92] \\
\hline & Daphnia pulex & $\mathrm{x}$ & $\mathrm{x}$ & & $\mathrm{x}$ & & & $\mathrm{x}$ & [92] \\
\hline Chydorus Sphaericus & Various & $\mathrm{x}$ & & & $\mathrm{x}$ & & $x$ & & [80] \\
\hline \multirow{2}{*}{ Ceriodaphnia cornuta } & Aeolosoma sp. & & $\mathrm{x}$ & $\mathrm{x}$ & $\mathrm{x}$ & & & $\mathrm{x}$ & {$[102]$} \\
\hline & Skiffia lermae & & $\mathrm{x}$ & $\mathrm{x}$ & $\mathrm{x}$ & & & $\mathrm{x}$ & {$[102]$} \\
\hline \multirow{7}{*}{ Ceriodaphnia dubia } & Aeolosoma sp. & & $\mathrm{x}$ & $\mathrm{x}$ & $\mathrm{x}$ & & & $\mathrm{x}$ & {$[102]$} \\
\hline & Chaoborus sp. & $\mathrm{x}$ & & & n.a. & n.a. & & $\mathrm{x}$ & [91] \\
\hline & $\begin{array}{c}\text { Cnesterodon } \\
\text { decemmaculatus }\end{array}$ & $\mathrm{x}$ & & & n.a. & n.a. & & $\mathrm{x}$ & {$[58]$} \\
\hline & Macrobrachium borellii & $\mathrm{x}$ & & & n.a. & n.a. & & $\mathrm{x}$ & [91] \\
\hline & Melanotaenia duboulayi & $\mathrm{x}$ & & & n.a. & n.a. & & $\mathrm{x}$ & [98] \\
\hline & Skiffia lermae & & $\mathrm{x}$ & $\mathrm{x}$ & $\mathrm{x}$ & & & $\mathrm{x}$ & {$[102]$} \\
\hline & Trichodactylus borellianus & $\mathrm{x}$ & & & n.a. & n.a. & & $\mathrm{x}$ & [91] \\
\hline \multirow{2}{*}{ Ceriodaphnia reticulata } & Mesocyclops leuckarti & $\mathrm{x}$ & $\mathrm{x}$ & & $\mathrm{x}$ & & & $\mathrm{x}$ & [95] \\
\hline & Rutilus rutilus & $\mathrm{x}$ & & $\mathrm{x}$ & $\mathrm{x}$ & & & $\mathrm{x}$ & [81] \\
\hline \multirow{2}{*}{ Copepoda } & Gambusia hubbsi & & $\mathrm{x}$ & & n.a. & n.a. & & $\mathrm{x}$ & [33] \\
\hline & Rutilus rutilus & $\mathrm{x}$ & $\mathrm{x}$ & & n.a. & n.a. & $\mathrm{x}$ & & {$[65]$} \\
\hline Cyclops abyssorum & Fish & $\mathrm{x}$ & & & n.a. & n.a. & $\mathrm{x}$ & & {$[48]$} \\
\hline Daphnia ambigua & Chaoborus sp. & & $\mathrm{x}$ & & $\mathrm{x}$ & & & $\mathrm{x}$ & [143] \\
\hline Daphnia atkinsoni & Triops cancriformis & & $\mathrm{x}$ & & & $\mathrm{x}$ & & $\mathrm{x}$ & {$[154,155]$} \\
\hline \multirow{2}{*}{ Daphnia barbata } & Notonecta glauca & & $\mathrm{x}$ & & $\mathrm{x}$ & & & $\mathrm{x}$ & {$[28]$} \\
\hline & Triops cancriformis & & $\mathrm{x}$ & & $\mathrm{x}$ & & & $\mathrm{x}$ & {$[28,157]$} \\
\hline
\end{tabular}


Table A1. Cont.

\begin{tabular}{|c|c|c|c|c|c|c|c|c|c|}
\hline Zooplankton Species & Predator & Behaviour & Morphology & Life-History & Single Clone & Multiple Clones & Field Study & Laboratory Study & Source \\
\hline \multirow{7}{*}{ Daphnia cucullata } & Chaoborus flavicans & & $\mathrm{x}$ & & $\mathrm{x}$ & & & $\mathrm{x}$ & {$[22,223,233$} \\
\hline & Chaoborus sp. & & $\mathrm{x}$ & & $\mathrm{x}$ & & & $\mathrm{x}$ & [143] \\
\hline & Cyclops sp. & & $\mathrm{x}$ & & $\mathrm{x}$ & & & $\mathrm{x}$ & {$[202,223]$} \\
\hline & Leptodora kindtii & & $\mathrm{x}$ & & $\mathrm{x}$ & & & $\mathrm{x}$ & {$[202]$} \\
\hline & Fish & $\mathrm{x}$ & & & n.a. & n.a. & $\mathrm{x}$ & & {$[80]$} \\
\hline & Phoxinus phoxinus & & $\mathrm{x}$ & & $\mathrm{x}$ & & & $\mathrm{x}$ & [66] \\
\hline & Rutilus rutilus & & & $\mathrm{x}$ & $\mathrm{x}$ & & & $\mathrm{x}$ & [205] \\
\hline Daphnia curvirostris & Chaoborus crystallinus & & $\mathrm{x}$ & & & $\mathrm{x}$ & & $\mathrm{x}$ & [107] \\
\hline \multirow{2}{*}{ Daphnia dentifera } & Chaoborus punctipennis & & & $\mathrm{x}$ & & $\mathrm{x}$ & & $\mathrm{x}$ & [212] \\
\hline & Lepomis macrochirus & & & $\mathrm{x}$ & & $\mathrm{x}$ & & $\mathrm{x}$ & [212] \\
\hline \multirow{12}{*}{ Daphnia galeata } & Chaoborus sp. & & & $\mathrm{x}$ & & $\mathrm{x}$ & $\mathrm{x}$ & $\mathrm{x}$ & [195] \\
\hline & Gasterosteus aculeatus & & & $\mathrm{x}$ & & $\mathrm{x}$ & & $\mathrm{x}$ & [222] \\
\hline & Fish & $\mathrm{x}$ & & & n.a. & n.a. & $\mathrm{x}$ & & {$[54,60]$} \\
\hline & Lepomis macrochirus & & $\mathrm{x}$ & & & $\mathrm{x}$ & & $\mathrm{x}$ & [101] \\
\hline & Leucaspius delineatus & $\mathrm{x}$ & & & $\mathrm{x}$ & & & $\mathrm{x}$ & {$[60]$} \\
\hline & \multirow{2}{*}{ Leuciscus idus } & & $\mathrm{x}$ & $\mathrm{x}$ & & $\mathrm{x}$ & & $\mathrm{x}$ & [4] \\
\hline & & & & $\mathrm{x}$ & & $\mathrm{x}$ & $\mathrm{x}$ & $\mathrm{x}$ & [195] \\
\hline & Mochlonyx fuliginosus & $\mathrm{x}$ & & & n.a. & n.a. & $\mathrm{x}$ & & [54] \\
\hline & \multirow{2}{*}{ Perca fluviatilis } & $\mathrm{x}$ & & & $\mathrm{x}$ & & & $\mathrm{x}$ & [72] \\
\hline & & & & $\mathrm{x}$ & & $\mathrm{x}$ & & $\mathrm{x}$ & {$[222]$} \\
\hline & Rhodeus sericeus amarus & & & $\mathrm{x}$ & & $\mathrm{x}$ & & $\mathrm{x}$ & [213] \\
\hline & $\begin{array}{c}\text { Scardinius } \\
\text { erythrophthalmus }\end{array}$ & & & $\mathrm{x}$ & & $\mathrm{x}$ & & $\mathrm{x}$ & [203] \\
\hline Daphnia hrbaceki & Chaoborus crystallinus & & $\mathrm{x}$ & & & $\mathrm{x}$ & & $\mathrm{x}$ & [107] \\
\hline
\end{tabular}


Table A1. Cont.

\begin{tabular}{|c|c|c|c|c|c|c|c|c|c|}
\hline Zooplankton Species & Predator & Behaviour & Morphology & Life-History & Single Clone & Multiple Clones & Field Study & Laboratory Study & Source \\
\hline \multirow{5}{*}{ Daphnia hyalina } & Chaoborus sp. & & & $\mathrm{x}$ & & $\mathrm{x}$ & $\mathrm{x}$ & $\mathrm{x}$ & [195] \\
\hline & Leuciscus idus & & & $\mathrm{x}$ & & $\mathrm{x}$ & $\mathrm{x}$ & $\mathrm{x}$ & [195] \\
\hline & Perca fluviatilis & $\mathrm{x}$ & & & $\mathrm{x}$ & & & $\mathrm{x}$ & [72] \\
\hline & Poxinus phoxinus & & $\mathrm{x}$ & & $\mathrm{x}$ & & & $\mathrm{x}$ & {$[66]$} \\
\hline & Rutilus rutilus & & & $\mathrm{x}$ & $\mathrm{x}$ & & & $\mathrm{x}$ & [205] \\
\hline \multirow{8}{*}{ Daphnia hyalina $x$ galeata } & Chaoborus sp. & & & $\mathrm{x}$ & & $\mathrm{x}$ & $\mathrm{x}$ & $\mathrm{x}$ & [195] \\
\hline & Fish & $\mathrm{x}$ & & & $\mathrm{x}$ & & & $\mathrm{x}$ & [79] \\
\hline & Leuciscus idus & & & $\mathrm{x}$ & & $\mathrm{x}$ & $\mathrm{x}$ & $\mathrm{x}$ & [195] \\
\hline & \multirow{2}{*}{ Perca fluviatilis } & $\mathrm{x}$ & & & $\mathrm{x}$ & & & $\mathrm{x}$ & {$[59,72]$} \\
\hline & & & & $\mathrm{x}$ & $\mathrm{x}$ & & & $\mathrm{x}$ & [199] \\
\hline & \multirow{2}{*}{ Rutilus rutilus } & $\mathrm{x}$ & & $\mathrm{x}$ & $\mathrm{x}$ & & & $\mathrm{x}$ & {$[81]$} \\
\hline & & & & $\mathrm{x}$ & $\mathrm{x}$ & & & $\mathrm{x}$ & [210] \\
\hline & Rhodeus sericeus amarus & & & $\mathrm{x}$ & & $\mathrm{x}$ & & $\mathrm{x}$ & [213] \\
\hline Daphnia laevis & Oreochromis spp. & & $\mathrm{x}$ & $\mathrm{x}$ & & $\mathrm{x}$ & & $\mathrm{x}$ & [45] \\
\hline \multirow{3}{*}{ Daphnia longicephala } & \multirow{2}{*}{ Notonecta glauca } & & $\mathrm{x}$ & & $\mathrm{x}$ & & & $\mathrm{x}$ & {$[22,233]$} \\
\hline & & & $\mathrm{x}$ & $\mathrm{x}$ & $\mathrm{x}$ & & & $\mathrm{x}$ & [248] \\
\hline & Notonecta sp. & & $\mathrm{x}$ & & $\mathrm{x}$ & & & $\mathrm{x}$ & {$[143,245]$} \\
\hline \multirow{9}{*}{ Daphnia longispina } & Various & $\mathrm{x}$ & & & $\mathrm{x}$ & & $\mathrm{x}$ & & [80] \\
\hline & Coregonus alba & & $\mathrm{x}$ & $\mathrm{x}$ & n.a. & n.a. & $\mathrm{x}$ & & [117] \\
\hline & Chaoborus flavicans & & $\mathrm{x}$ & & n.a. & n.a. & $x$ & & [144] \\
\hline & Chaoborus sp. & & $x$ & & & $x$ & $x$ & $x$ & [145] \\
\hline & Fish & $\mathrm{x}$ & & & n.a. & n.a. & $\mathrm{x}$ & & [80] \\
\hline & Gambusia holbrooki & & & $\mathrm{x}$ & $\mathrm{x}$ & & & $\mathrm{x}$ & [220] \\
\hline & Lepomis gibbosus & & & $\mathrm{x}$ & $\mathrm{x}$ & & & $\mathrm{x}$ & [220] \\
\hline & Notonecta glauca & & $\mathrm{x}$ & & $\mathrm{x}$ & & & $\mathrm{x}$ & {$[30]$} \\
\hline & $\begin{array}{c}\text { Scardinius } \\
\text { erythrophthalmus }\end{array}$ & $\mathrm{x}$ & & $\mathrm{x}$ & & $\mathrm{x}$ & & $\mathrm{x}$ & [240] \\
\hline
\end{tabular}


Table A1. Cont.

\begin{tabular}{|c|c|c|c|c|c|c|c|c|c|}
\hline Zooplankton Species & Predator & Behaviour & Morphology & Life-History & Single Clone & Multiple Clones & Field Study & Laboratory Study & Source \\
\hline \multirow{7}{*}{ Daphnia lumholtzi } & Chaoborus flavicans & & $\mathrm{x}$ & & & $\mathrm{x}$ & & $\mathrm{x}$ & [131] \\
\hline & Chaoborus punctipennis & & $\mathrm{x}$ & $\mathrm{x}$ & $\mathrm{x}$ & & & $\mathrm{x}$ & [116] \\
\hline & \multirow{2}{*}{ Gasterosteus aculeatus } & & $\mathrm{x}$ & & & $\mathrm{x}$ & & $\mathrm{x}$ & [131] \\
\hline & & & $\mathrm{x}$ & & $\mathrm{x}$ & & & $\mathrm{x}$ & [233] \\
\hline & Lepomis macrochirus & & $\mathrm{x}$ & $\mathrm{x}$ & $\mathrm{x}$ & & & $\mathrm{x}$ & [116] \\
\hline & Leucaspius delineatus & & $\mathrm{x}$ & $\mathrm{x}$ & & $\mathrm{x}$ & & $\mathrm{x}$ & [132] \\
\hline & Phoxinus phoxinus & & $\mathrm{x}$ & & $\mathrm{x}$ & & & $\mathrm{x}$ & {$[22,143]$} \\
\hline \multirow{19}{*}{ Daphnia magna } & Abramis brama & $\mathrm{x}$ & & & & $\mathrm{x}$ & & $\mathrm{x}$ & [96] \\
\hline & \multirow{2}{*}{ Carassius carassius } & & & $\mathrm{x}$ & $\mathrm{x}$ & & & $\mathrm{x}$ & {$[192,193]$} \\
\hline & & $\mathrm{x}$ & & & $\mathrm{x}$ & & & $\mathrm{x}$ & [232] \\
\hline & \multirow{2}{*}{ Chaoborus crystallinus } & & & $\mathrm{x}$ & $\mathrm{x}$ & & & $\mathrm{x}$ & [241] \\
\hline & & $\mathrm{x}$ & & & & $\mathrm{x}$ & & $\mathrm{x}$ & [96] \\
\hline & Chaoborus obscuripes & & & $\mathrm{x}$ & $\mathrm{x}$ & & & $\mathrm{x}$ & [241] \\
\hline & Danio rerio & $\mathrm{x}$ & & & & $\mathrm{x}$ & & $\mathrm{x}$ & {$[96]$} \\
\hline & \multirow{2}{*}{ Fish } & $\mathrm{x}$ & $\mathrm{x}$ & $\mathrm{x}$ & & $\mathrm{x}$ & & $\mathrm{x}$ & [124] \\
\hline & & & & $\mathrm{x}$ & $\mathrm{x}$ & & & $\mathrm{x}$ & [188] \\
\hline & Gambusia holbrooki & & & $\mathrm{x}$ & $\mathrm{x}$ & & & $\mathrm{x}$ & [183] \\
\hline & Gasterosteus aculeatus & $\mathrm{x}$ & & $\mathrm{x}$ & $\mathrm{x}$ & & & $\mathrm{x}$ & [99] \\
\hline & Ischnura elegans & $\mathrm{x}$ & & & n.a. & n.a. & & $\mathrm{x}$ & {$[88]$} \\
\hline & Lepomis gibbosus & & & $\mathrm{x}$ & & $\mathrm{x}$ & & $\mathrm{x}$ & {$[208]$} \\
\hline & \multirow{2}{*}{ Leucaspius delineatus } & $\mathrm{x}$ & & & & $\mathrm{x}$ & & $\mathrm{x}$ & [96] \\
\hline & & & & $\mathrm{x}$ & $\mathrm{x}$ & & & $\mathrm{x}$ & {$[189,194]$} \\
\hline & \multirow{2}{*}{ Leuciscus idus } & & & $\mathrm{x}$ & $x$ & & & $x$ & [221] \\
\hline & & & & $\mathrm{x}$ & & $\mathrm{x}$ & & $\mathrm{x}$ & {$[190,206]$} \\
\hline & Notonecta glauca & & & $\mathrm{x}$ & $\mathrm{x}$ & & & $\mathrm{x}$ & [183] \\
\hline & Notonecta sp. & $\mathrm{x}$ & & & & $\mathrm{x}$ & & $\mathrm{x}$ & [96] \\
\hline
\end{tabular}


Table A1. Cont.

\begin{tabular}{|c|c|c|c|c|c|c|c|c|c|}
\hline Zooplankton Species & Predator & Behaviour & Morphology & Life-History & Single Clone & Multiple Clones & Field Study & Laboratory Study & Source \\
\hline & \multirow{2}{*}{ Perca fluviatilis } & & & $\mathrm{x}$ & $\mathrm{x}$ & & & $\mathrm{x}$ & {$[119,120]$} \\
\hline & & $\mathrm{x}$ & & & $\mathrm{x}$ & & & $\mathrm{x}$ & [72] \\
\hline & Pseudorasbora parva & $\mathrm{x}$ & & & n.a. & n.a. & & $\mathrm{x}$ & [90] \\
\hline & \multirow{2}{*}{ Rhodeus amarus } & & & $\mathrm{x}$ & & $\mathrm{x}$ & & $\mathrm{x}$ & [190] \\
\hline & & & & $\mathrm{x}$ & $x$ & & & & [214] \\
\hline & Rutilus rutilus & $x$ & & & $x$ & & & $x$ & [227] \\
\hline & \multirow{2}{*}{ Salmo trutta } & $\mathrm{x}$ & & $\mathrm{x}$ & $\mathrm{x}$ & & & $\mathrm{x}$ & [23] \\
\hline & & & & $\mathrm{x}$ & $x$ & & & $x$ & [236] \\
\hline & \multirow{4}{*}{ Triops cancriformis } & & $\mathrm{x}$ & & $\mathrm{x}$ & & & $x$ & {$[156,158]$} \\
\hline & & & $\mathrm{x}$ & & & $\mathrm{x}$ & & $x$ & [108] \\
\hline & & & & $\mathrm{x}$ & & $x$ & & $\mathrm{x}$ & [191] \\
\hline & & & & $\mathrm{x}$ & $\mathrm{x}$ & & & $\mathrm{x}$ & {$[211,214]$} \\
\hline \multirow{6}{*}{ Daphnia mendotae } & \multirow{2}{*}{ Bythotrephes longimanus } & & $\mathrm{x}$ & & & $x$ & & $x$ & [161] \\
\hline & & $\mathrm{x}$ & & $\mathrm{x}$ & n.a. & n.a. & & $x$ & [55] \\
\hline & Chaoborus punctipennis & & $\mathrm{x}$ & & n.a. & n.a. & & $\mathrm{x}$ & [201] \\
\hline & Lepomis macrochirus & & & $x$ & $x$ & & & $x$ & [181] \\
\hline & Leptodora kindtii & & $\mathrm{x}$ & & n.a. & n.a. & & $x$ & [201] \\
\hline & Perca flavescens & $x$ & & $x$ & n.a. & n.a. & $x$ & & [82] \\
\hline Daphnia middendorffiana & Phoxinus phoxinus & & $\mathrm{x}$ & & $x$ & & & $x$ & [66] \\
\hline \multirow{2}{*}{ Daphnia minnehaha } & Chaoborus americanus & & $x$ & & & $x$ & $x$ & & [27] \\
\hline & Chaoborus trivitattus & & $x$ & & & $x$ & $x$ & & [27] \\
\hline Daphnia obtusa & Micropterus salmoides & $\mathrm{x}$ & & & $\mathrm{x}$ & & & $\mathrm{x}$ & [101] \\
\hline
\end{tabular}


Table A1. Cont.

\begin{tabular}{|c|c|c|c|c|c|c|c|c|c|}
\hline Zooplankton Species & Predator & Behaviour & Morphology & Life-History & Single Clone & Multiple Clones & Field Study & Laboratory Study & Source \\
\hline \multirow{27}{*}{ Daphnia pulex } & \multirow{2}{*}{ Alburnus alburnus } & $x$ & & & $\mathrm{x}$ & & & $\mathrm{x}$ & {$[49,218,219]$} \\
\hline & & $\mathrm{x}$ & & & n.a. & n.a. & & $\mathrm{x}$ & [49] \\
\hline & Alburnus escherichi & & & $x$ & n.a. & n.a. & & $x$ & [246] \\
\hline & \multirow{6}{*}{ Chaoborus americanus } & $\mathrm{x}$ & & & & $\mathrm{x}$ & & $\mathrm{x}$ & [56] \\
\hline & & & & $\mathrm{x}$ & & $\mathrm{x}$ & & $\mathrm{x}$ & {$[197,204]$} \\
\hline & & & $\mathrm{x}$ & & $\mathrm{x}$ & & & $\mathrm{x}$ & {$[243,247]$} \\
\hline & & & $x$ & & & $\mathrm{x}$ & $\mathrm{x}$ & & [27] \\
\hline & & $x$ & & $\mathrm{x}$ & $x$ & & $\mathrm{x}$ & & [84] \\
\hline & & & $\mathrm{x}$ & $\mathrm{x}$ & $\mathrm{x}$ & & & $\mathrm{x}$ & [244] \\
\hline & \multirow[t]{2}{*}{ Chaoborus crystallinus } & & $x$ & & & $x$ & & $x$ & [107] \\
\hline & & & & $x$ & $x$ & & & $x$ & [196] \\
\hline & \multirow{8}{*}{ Chaoborus flavicans } & $\mathrm{x}$ & & & & $x$ & & $\mathrm{x}$ & [44] \\
\hline & & $x$ & $x$ & $x$ & & $\mathrm{x}$ & & $\mathrm{x}$ & [42] \\
\hline & & & $\mathrm{x}$ & & $\mathrm{x}$ & & & $\mathrm{x}$ & {$[14,148,233]$} \\
\hline & & & $\mathrm{x}$ & & n.a. & n.a. & $\mathrm{x}$ & & [144] \\
\hline & & $x$ & & & & $x$ & & $x$ & [44] \\
\hline & & & $\mathrm{x}$ & & & $\mathrm{x}$ & & $\mathrm{x}$ & [109] \\
\hline & & & $x$ & $x$ & $\mathrm{x}$ & & & $x$ & [198] \\
\hline & & & & $\mathrm{x}$ & & $\mathrm{x}$ & & $\mathrm{x}$ & {$[211,215]$} \\
\hline & Chaoborus obscuripes & & $x$ & & $\mathrm{x}$ & & & $\mathrm{x}$ & [30] \\
\hline & Chaoborus sp. & & $x$ & & $x$ & & & $x$ & {$[143,245]$} \\
\hline & \multirow{6}{*}{ Chaoborus trivitattus } & $\mathrm{x}$ & & & & $\mathrm{x}$ & & $\mathrm{x}$ & [44] \\
\hline & & $\mathrm{x}$ & $\mathrm{x}$ & $\mathrm{x}$ & & $x$ & & $\mathrm{x}$ & [42] \\
\hline & & $\mathrm{x}$ & $\mathrm{x}$ & & & $\mathrm{x}$ & $\mathrm{x}$ & & [182] \\
\hline & & & $\mathrm{x}$ & & & $\mathrm{x}$ & $\mathrm{x}$ & & [27] \\
\hline & & $x$ & & & & $x$ & & $x$ & [44] \\
\hline & & $\mathrm{x}$ & & $\mathrm{x}$ & $\mathrm{x}$ & & $\mathrm{x}$ & & [84] \\
\hline
\end{tabular}


Table A1. Cont.

\begin{tabular}{|c|c|c|c|c|c|c|c|c|c|}
\hline Zooplankton Species & Predator & Behaviour & Morphology & Life-History & Single Clone & Multiple Clones & Field Study & Laboratory Study & Source \\
\hline & Gasterosteus aculeatus & & & $\mathrm{x}$ & $\mathrm{x}$ & & & $\mathrm{x}$ & [196] \\
\hline & Mesocyclops leuckarti & $\mathrm{x}$ & $\mathrm{x}$ & & $\mathrm{x}$ & & & $\mathrm{x}$ & [95] \\
\hline & & $\mathrm{x}$ & & & & $\mathrm{x}$ & & $\mathrm{x}$ & [44] \\
\hline & Notemigonus crysoleucas & $\mathrm{x}$ & $\mathrm{x}$ & $\mathrm{x}$ & & $\mathrm{x}$ & & $\mathrm{x}$ & [42] \\
\hline & & $\mathrm{x}$ & & & & $\mathrm{x}$ & & $\mathrm{x}$ & [44] \\
\hline & Phoxinus phoxinus & & $\mathrm{x}$ & & $\mathrm{x}$ & & & $\mathrm{x}$ & [66] \\
\hline & $\begin{array}{c}\text { Scardinius } \\
\text { erythrophthalmus }\end{array}$ & & & $\mathrm{x}$ & & $\mathrm{x}$ & & $\mathrm{x}$ & [203] \\
\hline \multirow{12}{*}{ Daphnia pulicaria } & Chaoborus flavicans & $\mathrm{x}$ & $\mathrm{x}$ & $\mathrm{x}$ & & $\mathrm{x}$ & & $\mathrm{x}$ & [42] \\
\hline & \multirow{2}{*}{ Chaoborus sp. } & & & $\mathrm{x}$ & & $\mathrm{x}$ & & $\mathrm{x}$ & [242] \\
\hline & & $\mathrm{x}$ & & & $\mathrm{x}$ & & & $\mathrm{x}$ & [97] \\
\hline & Chaoborus trivitattus & $\mathrm{x}$ & $\mathrm{x}$ & $\mathrm{x}$ & & $\mathrm{x}$ & & $\mathrm{x}$ & [42] \\
\hline & \multirow{4}{*}{ Lepomis macrochirus } & & & $\mathrm{x}$ & $\mathrm{x}$ & & & $\mathrm{x}$ & [207] \\
\hline & & & & $\mathrm{x}$ & $\mathrm{x}$ & & & $\mathrm{x}$ & [181] \\
\hline & & $\mathrm{x}$ & & & n.a. & n.a. & & $\mathrm{x}$ & [57] \\
\hline & & $\mathrm{x}$ & & & $\mathrm{x}$ & & & $\mathrm{x}$ & [97] \\
\hline & Leucaspius delineatus & & $\mathrm{x}$ & $\mathrm{x}$ & & $\mathrm{x}$ & & $\mathrm{x}$ & [132] \\
\hline & Notemigonus crysoleucas & $\mathrm{x}$ & $\mathrm{x}$ & $\mathrm{x}$ & & $\mathrm{x}$ & & $\mathrm{x}$ & [42] \\
\hline & Percaflavescens & $\mathrm{x}$ & & $\mathrm{x}$ & n.a. & n.a. & $\mathrm{x}$ & & [82] \\
\hline & Rutilus rutilus & & & $\mathrm{x}$ & $\mathrm{x}$ & & & $\mathrm{x}$ & [210] \\
\hline \multirow{4}{*}{ Daphnia similis } & Chaoborus obscuripes & & & $\mathrm{x}$ & $\mathrm{x}$ & & & $\mathrm{x}$ & [184] \\
\hline & Gasterosteus aculeatus & & & $\mathrm{x}$ & $\mathrm{x}$ & & & $\mathrm{x}$ & [184] \\
\hline & Lepomis macrochirus & & $\mathrm{x}$ & & & $\mathrm{x}$ & & $\mathrm{x}$ & [101] \\
\hline & Oreochromis spp. & & $\mathrm{x}$ & $\mathrm{x}$ & $\mathrm{x}$ & & & $\mathrm{x}$ & [45] \\
\hline \multirow{3}{*}{ Daphnia similoides sinensis } & Cyclops vicinus & & $\mathrm{x}$ & & n.a. & n.a. & $\mathrm{x}$ & & [123] \\
\hline & Leptodora richardi & & $\mathrm{x}$ & & n.a. & n.a. & $\mathrm{x}$ & & [123] \\
\hline & Neosalanx taihuensis & & $\mathrm{x}$ & & n.a. & n.a. & $\mathrm{x}$ & & [123] \\
\hline
\end{tabular}


Table A1. Cont.

\begin{tabular}{|c|c|c|c|c|c|c|c|c|c|}
\hline Zooplankton Species & Predator & Behaviour & Morphology & Life-History & Single Clone & Multiple Clones & Field Study & Laboratory Study & Source \\
\hline Daphnia spinulata & Oreochromis spp. & & $\mathrm{x}$ & $\mathrm{x}$ & $\mathrm{x}$ & & & $\mathrm{x}$ & [45] \\
\hline \multirow{3}{*}{ Daphnia sp. } & Coregonus alba & & $\mathrm{x}$ & $\mathrm{x}$ & n.a. & n.a. & $\mathrm{x}$ & & [117] \\
\hline & Lepomis macrochirus & $\mathrm{x}$ & & & n.a. & n.a. & $\mathrm{x}$ & & [61] \\
\hline & Rutilus rutilus & $\mathrm{x}$ & & & n.a. & n.a. & $\mathrm{x}$ & & [83] \\
\hline \multirow{4}{*}{ Diaphanosoma brachyurum } & Fish & $\mathrm{x}$ & & & n.a. & n.a. & $\mathrm{x}$ & & {$[54,80]$} \\
\hline & Mesocyclops leuckarti & $\mathrm{x}$ & $\mathrm{x}$ & & $\mathrm{x}$ & & & $\mathrm{x}$ & [95] \\
\hline & Mochlonyx fuliginosus & $\mathrm{x}$ & & & n.a. & n.a. & $\mathrm{x}$ & & [54] \\
\hline & Various & $\mathrm{x}$ & & & $\mathrm{x}$ & & $\mathrm{x}$ & & [80] \\
\hline Diaphanosoma birgei & $\begin{array}{c}\text { Hyphessobrycon } \\
\text { bifasciatus }\end{array}$ & & & $\mathrm{x}$ & & $\mathrm{x}$ & & $\mathrm{x}$ & [187] \\
\hline Eubosmina coregoni & Various & $\mathrm{x}$ & & & $\mathrm{x}$ & & $\mathrm{x}$ & & [80] \\
\hline $\begin{array}{c}\text { Eubosmina coregoni } \\
\text { coregoni }\end{array}$ & Mesocyclops leuckarti & & $\mathrm{x}$ & & & $\mathrm{x}$ & & $\mathrm{x}$ & [169] \\
\hline Eubosmina coregoni gibbera & Mesocyclops leuckarti & & $\mathrm{x}$ & & & $x$ & & $\mathrm{x}$ & [169] \\
\hline Eubosmina coregoni kessleri & Mesocyclops leuckarti & & $\mathrm{x}$ & & & $\mathrm{x}$ & & $\mathrm{x}$ & [169] \\
\hline $\begin{array}{c}\text { Eubosmina coregoni } \\
\text { thersites }\end{array}$ & Mesocyclops leuckarti & & $\mathrm{x}$ & & & $\mathrm{x}$ & & $\mathrm{x}$ & [169] \\
\hline Eubosmina longispina & Coregonus alba & & $\mathrm{x}$ & $\mathrm{x}$ & n.a. & n.a. & $\mathrm{x}$ & & [117] \\
\hline Eudiaptomus gracilis & Fish & $\mathrm{x}$ & & & n.a. & n.a. & $\mathrm{x}$ & & [48] \\
\hline \multirow{4}{*}{ Keratella tropica } & \multirow{2}{*}{ Asplanchna brightwelli } & & $\mathrm{x}$ & $\mathrm{x}$ & n.a. & n.a. & & $\mathrm{x}$ & {$[176]$} \\
\hline & & & $\mathrm{x}$ & & n.a. & n.a. & & $\mathrm{x}$ & [179] \\
\hline & \multirow{2}{*}{ Daphnia pulex } & & $\mathrm{x}$ & $\mathrm{x}$ & n.a. & n.a. & & $\mathrm{x}$ & [176] \\
\hline & & & $\mathrm{x}$ & & n.a. & n.a. & & $\mathrm{x}$ & [179] \\
\hline \multirow{2}{*}{ Moina macrocopa } & Chaoborus obscuripes & & & $\mathrm{x}$ & $\mathrm{x}$ & & & $\mathrm{x}$ & [184] \\
\hline & Gasterosteus aculeatus & & & $\mathrm{x}$ & $\mathrm{x}$ & & & $\mathrm{x}$ & [184] \\
\hline \multirow[b]{2}{*}{ Moina micrura } & Gasterosteus aculeatus & & & $\mathrm{x}$ & $\mathrm{x}$ & & & $\mathrm{x}$ & [187] \\
\hline & $\begin{array}{c}\text { Hyphessobrycon } \\
\text { bifasciatus }\end{array}$ & & & $\mathrm{x}$ & & $\mathrm{x}$ & & $\mathrm{x}$ & [187] \\
\hline Neomysis integer & Perca fluviatilis & $\mathrm{x}$ & & & n.a. & n.a. & & $\mathrm{x}$ & [89] \\
\hline
\end{tabular}


Table A1. Cont.

\begin{tabular}{|c|c|c|c|c|c|c|c|c|c|}
\hline Zooplankton Species & Predator & Behaviour & Morphology & Life-History & Single Clone & Multiple Clones & Field Study & Laboratory Study & Source \\
\hline \multirow{4}{*}{ Notodiaptomus conifer } & Chaoborus sp. & $\mathrm{x}$ & & & n.a. & n.a. & & $\mathrm{x}$ & [91] \\
\hline & $\begin{array}{c}\text { Cnesterodon } \\
\text { decermmaculatus }\end{array}$ & $\mathrm{x}$ & & & n.a. & n.a. & & $\mathrm{x}$ & [58] \\
\hline & Macrobrachium borellii & $\mathrm{x}$ & & & n.a. & n.a. & & $\mathrm{x}$ & [91] \\
\hline & Trichodactylus borellianus & $\mathrm{x}$ & & & n.a. & n.a. & & $\mathrm{x}$ & [91] \\
\hline Plationus macracanthus & Asplanchna brightwellii & & $\mathrm{x}$ & $\mathrm{x}$ & n.a. & n.a. & & $\mathrm{x}$ & [178] \\
\hline Praunus flexuosus & Perca fluviatilis & $\mathrm{x}$ & & & n.a. & n.a. & & $\mathrm{x}$ & [89] \\
\hline Pseudosida variabilis & $\begin{array}{c}\text { Cnesterodon } \\
\text { decemmaculatus }\end{array}$ & $\mathrm{x}$ & & & n.a. & n.a. & & $\mathrm{x}$ & [58] \\
\hline \multirow{2}{*}{ Simocephalus serrulatus } & Aeolosoma sp. & & $\mathrm{x}$ & $\mathrm{x}$ & $\mathrm{x}$ & & & $\mathrm{x}$ & [102] \\
\hline & Skiffia lermae & & $\mathrm{x}$ & $\mathrm{x}$ & $\mathrm{x}$ & & & $\mathrm{x}$ & [102] \\
\hline \multirow{2}{*}{ Simocephalus vetulus } & Aeolosoma sp. & & $\mathrm{x}$ & $\mathrm{x}$ & $\mathrm{x}$ & & & $\mathrm{x}$ & [102] \\
\hline & Skiffia lermae & & $\mathrm{x}$ & $\mathrm{x}$ & $\mathrm{x}$ & & & $x$ & [102] \\
\hline Various zooplankton & Chaoborus flavicans & $\mathrm{x}$ & & & n.a. & n.a. & $\mathrm{x}$ & & [26] \\
\hline
\end{tabular}




\section{References}

1. Werner, E.E.; Peacor, S.D. A review of trait-mediated indirect interactions in ecological communities. Ecology 2003, 84, 1083-1100. [CrossRef]

2. Boaden, A.E.; Kingsford, M.J. Predators drive community structure in coral reef fish assemblages. Ecosphere 2015, 6, 1-33. [CrossRef]

3. Kuchta, S.; Svensson, E.I. Predator-Mediated Natural Selection on the Wings of the Damselfly Calopteryx splendens: Differences in Selection among Trait Types. Am. Nat. 2014, 184, 91-109. [CrossRef]

4. Tams, V.; Lüneburg, J.; Seddar, L.; Detampel, J.P.; Cordellier, M. Intraspecific phenotypic variation in life history traits of Daphnia galeata populations in response to fish kairomones. PeerJ 2018, 6, e5746. [CrossRef]

5. Karban, R.; Baldwin, I.T. Induced Responses to Herbivory; University of Chicago Press: Chicago, IL, USA, 2013; Volume 1, pp. 1-330.

6. Agrawal, A.A. Agrawal Induced responses to herbivory and increased plant performance. Science 1998, 279, 1201-1202. [CrossRef]

7. Tollrian, R.; Harvell, C.D. The Ecology and Evolution of Induced Defenses, 1st ed.; Princeton University Press: Princeton, NJ, USA, 1999; Volume 1, pp. 1-377.

8. Dicke, M.; Hilker, M. Induced plant defences: From molecular biology to evolutionary ecology. Basic Appl. Ecol. 2003, 4, 3-14. [CrossRef]

9. Jeschke, J.M.; Laforsch, C.; Tollrian, R. Animal Prey Defenses. In Encyclopedia of Ecology; Elsevier: Amsterdam, The Netherlands, 2008; pp. 189-194, ISBN 9780080914565.

10. Spitze, K.; Sadler, T.D. Evolution of a generalist genotype: Multivariate analysis of the adaptiveness of phenotypic plasticity. In Proceedings of the American Naturalist; The University of Chicago Press: Chicago, IL, USA, 1996; Volume 148, pp. 108-123.

11. Stearns, S.C. The Evolutionary Significance of Phenotypic Plasticity. Bioscience 1989, 39, 436-445. [CrossRef]

12. Laforsch, C.; Tollrian, R. Cyclomorphosis and Phenotypic Changes. In Encyclopedia of Inland Waters; Elsevier: Amsterdam, The Netherlands, 2009; pp. 643-650, ISBN 9780123706263.

13. Sakamoto, M.; Nagata, T.; Ha, J.Y.; Kimijima, S.; Hanazato, T.; Chang, K.H. Inducible defenses as factor determining trophic pathways in a food web. Hydrobiologia 2015, 743, 15-25. [CrossRef]

14. Weiss, L.C.; Albada, B.; Becker, S.M.; Meckelmann, S.W.; Klein, J.; Meyer, M.; Schmitz, O.J.; Sommer, U.; Leo, M.; Zagermann, J.; et al. Identification of Chaoborus kairomone chemicals that induce defences in Daphnia. Nat. Chem. Biol. 2018, 14, 1133-1139. [CrossRef]

15. Brancelj, A.; Čelhar, T.; Šiško, M. Four different head shapes in Daphnia hyalina (Leydig) induced by the presence of larvae of Chaoborus flavicans (Meigen). Hydrobiologia 1996, 339, 37-45. [CrossRef]

16. Kats, L.B.; Dill, L.M. The scent of death: Chemosensory assessment of predation risk by prey animals. Ecoscience 1998, 5, 361-394. [CrossRef]

17. Lass, S.; Spaak, P. Chemically induced anti-predator defences in plankton: A review. In Proceedings of the Hydrobiologia; Springer: Berlin/Heidelberg, Germany, 2003; Volume 491, pp. 221-239.

18. Korosi, J.B.; Kurek, J.; Smol, J.P. A review on utilizing Bosmina size structure archived in lake sediments to infer historic shifts in predation regimes. J. Plankton Res. 2013, 35, 444-460. [CrossRef]

19. Riessen, H.P.; Gilbert, J.J. Divergent developmental patterns of induced morphological defenses in rotifers and Daphnia: Ecological and evolutionary context. Limnol. Oceanogr. 2019, 64, 541-557. [CrossRef]

20. Brown, W.L.; Eisner, T.; Whittaker, R.H. Allomones and Kairomones: Transspecific Chemical Messengers. Bioscience 1970, 20, 21-22. [CrossRef]

21. Dodson, S.I. The ecological role of chemical stimuli for the zooplankton: Predator-induced morphology in Daphnia. Oecologia 1989, 78, 361-367. [CrossRef]

22. Laforsch, C.; Beccara, L.; Tollrian, R. Inducible defenses: The relevance of chemical alarm cues in Daphnia. Limnol. Oceanogr. 2006, 51, 1466-1472. [CrossRef]

23. Pestana, J.L.T.; Baird, D.J.; Soares, A.M.V.M. Predator threat assessment in Daphnia magna: The role of kairomones versus conspecific alarm cues. Mar. Freshw. Res. 2013, 64, 679-686. [CrossRef]

24. Brooks, J.L.; Dodson, S.I. Predation, body size, and composition of plankton. Science 1965, 150, 28-35. [CrossRef]

25. Kerfoot, W.C.; Weider, L.J. Experimental paleoecology (resurrection ecology): Chasing Van Valen's Red Queen hypothesis. Limnol. Oceanogr. 2004, 49, 1300-1316. [CrossRef] 
26. Lagergren, R.; Leberfinger, K.; Stenson, J.A.E. Seasonal and ontogenetic variation in diel vertical migration of Chaoborus flavicans and its effect on depth-selection behavior of other zooplankton. Limnol. Oceanogr. 2008, 53, 1083-1092. [CrossRef]

27. Riessen, H.P.; Trevett-Smith, J.B. Turning inducible defenses on and off: Adaptive responses of Daphnia to a gape-limited predator. Ecology 2009, 90, 3455-3469. [CrossRef]

28. Herzog, Q.; Laforsch, C. Modality matters for the expression of inducible defenses: Introducing a concept of predator modality. BMC Biol. 2013, 11, 113. [CrossRef]

29. Kruppert, S.; Horstmann, M.; Weiss, L.C.; Schaber, C.F.; Gorb, S.N.; Tollrian, R. Push or Pull? The light-weight architecture of the Daphnia pulex carapace is adapted to withstand tension, not compression. J. Morphol. 2016, 277, 1320-1328. [CrossRef]

30. Kruppert, S.; Horstmann, M.; Weiss, L.C.; Witzel, U.; Schaber, C.F.; Gorb, S.N.; Tollrian, R. Biomechanical properties of predator-induced body armour in the freshwater crustacean Daphnia. Sci. Rep. 2017, 7, 9750. [CrossRef]

31. Kruppert, S.; Deussen, L.; Weiss, L.C.; Horstmann, M.; Wolff, J.O.; Kleinteich, T.; Gorb, S.N.; Tollrian, R. Zooplankters' nightmare: The fast and efficient catching basket of larval phantom midges (Diptera: Chaoborus). PLoS ONE 2019, 14, e0214013. [CrossRef]

32. Colbourne, J.K.; Pfrender, M.E.; Gilbert, D.; Thomas, W.K.; Tucker, A.; Oakley, T.H.; Tokishita, S.; Aerts, A.; Arnold, G.J.; Basu, M.K.; et al. The ecoresponsive genome of Daphnia pulex. Science 2011, 331, 555-561. [CrossRef]

33. Lee, M.; Zhang, H.; Sha, Y.; Hegg, A.; Ugge, G.E.; Vinterstare, J.; Škerlep, M.; Pärssinen, V.; Herzog, S.D.; Björnerås, C.; et al. Low-latitude zooplankton pigmentation plasticity in response to multiple threats. $R$. Soc. Open Sci. 2019, 6. [CrossRef]

34. Lampert, W. Daphnia: Model herbivore, predator and prey. Polish J. Ecol. 2006, 54, 607-620.

35. Ebert, D. A genome for the environment. Science 2011, 331, 539-540. [CrossRef]

36. Seda, J.; Petrusek, A. Daphnia as a model organism in limnology and aquatic biology: Introductory remarks. J. Limnol. 2011, 70, 337-344. [CrossRef]

37. Stollewerk, A. The water flea Daphnia-a "new" model system for ecology and evolution? J. Biol. 2010, 9, 21. [CrossRef]

38. Weiss, L.C. Sensory ecology of predator-induced phenotypic plasticity. Front. Behav. Neurosci. 2019, 12, 330. [CrossRef]

39. Christjani, M.; Fink, P.; Von Elert, E. Phenotypic plasticity in three Daphnia genotypes in response to predator kairomone: Evidence for an involvement of chitin deacetylases. J. Exp. Biol. 2016, 219, 1697-1704. [CrossRef]

40. Gilbert, J.J. Spine development in Brachionus quadridentatus from an Australian billabong: Genetic variation and induction by Asplanchna. In Proceedings of the Hydrobiologia; Springer: Dordrecht, The Netherlands, 2001; Volume 446-447, pp. 19-28.

41. Juracka, P.J.; Korínek, V.; Petrusek, A. A new Central European species of the Daphnia curvirostris complex, Daphnia hrbaceki sp. nov. (Cladocera, Anomopoda, Daphniidae). Zootaxa 2010, 2718, 1-22. [CrossRef]

42. Boeing, W.J.; Ramcharan, C.W.; Riessen, H.P. Multiple predator defence strategies in Daphnia pulex and their relation to native habitat. J. Plankton Res. 2006, 28, 571-584. [CrossRef]

43. Riessen, H.P.; Young, J.D. Daphnia defense strategies in fishless lakes and ponds: One size does not fit all. J. Plankton Res. 2005, 27, 531-544. [CrossRef]

44. Boeing, W.J.; Ramcharan, C.W.; Riessen, H.P. Clonal variation in depth distribution of Daphnia pulex in response to predator kairomones. Arch. Hydrobiol. 2006, 166, 241-260. [CrossRef]

45. Tolardo, M.; Da Silva Ferrão-Filho, A.; Santangelo, J.M. Species and clone-dependent effects of tilapia fish (Cichlidae) on the morphology and life-history of temperate and tropical Daphnia. Ecol. Res. 2016, 31, 333-342. [CrossRef]

46. Stibor, H.; Lampert, W. Components of additive variance in life-history traits of Daphnia hyalina: Seasonal differences in the response to predator signals. Oikos 2000, 88, 129-138. [CrossRef]

47. Tollrian, R. Predator-induced morphological defenses: Costs, life history shifts, and maternal effects in Daphnia pulex. Ecology 1995, 76, 1691-1705. [CrossRef]

48. Winder, M.; Buergi, H.R.; Spaak, P. Seasonal vertical distribution of phytoplankton and copepod species in a high-mountain lake. Arch. Hydrobiol. 2003, 158, 197-213. [CrossRef] 
49. Beklioglu, M.; Gozen, A.G.; Yıldırım, F.; Zorlu, P.; Onde, S. Impact of food concentration on diel vertical migration behaviour of Daphnia pulex under fish predation risk. In Proceedings of the Hydrobiologia; Springer: Dordrecht, The Netherlands, 2008; Volume 614, pp. 321-327.

50. Dawidowicz, P.; Pijanowska, J.; Ciechomski, K. Vertical migration of Chaoborus larvae is induced by the presence of fish. Limnol. Oceanogr. 1990, 35, 1631-1637. [CrossRef]

51. Perticarrari, A.; Arcifa, M.S.; Rodrigues, R.A. Diel vertical migration of copepods in a Brazilian lake: A mechanism for decreasing risk of Chaoborus predation? Braz. J. Biol. 2004, 64, 289-298. [CrossRef]

52. Bayly, I.A.E. Aspects of Diel Vertical Migration in Zooplankton, and Its Enigma Variations. In Limnology in Australia; Springer: Dordrecht, The Netherlands, 1986; pp. 349-368.

53. Cuvier, G. The Animal Kingdom, Arranged After Its Organization; Forming a natural history of animals, and an introduction to comparative anatomy by the late Baron Cuvier; Orr and Co: London, UK, 1854; pp. 1-472.

54. Wojtal-Frankiewicz, A.; Frankiewicz, P.; Jurczak, T.; Grennan, J.; McCarthy, T.K. Comparison of fish and phantom midge influence on cladocerans diel vertical migration in a dual basin lake. Aquat. Ecol. 2010, 44, 243-254. [CrossRef]

55. Pangle, K.L.; Peacor, S.D. Non-lethal effect of the invasive predator Bythotrephes longimanus on Daphnia mendotae. Freshw. Biol. 2006, 51, 1070-1078. [CrossRef]

56. Oram, E.; Spitze, K. Depth selection by Daphnia pulex in response to Chaoborus kairomone. Freshw. Biol. 2013, 58, 409-415. [CrossRef]

57. Nihongi, A.; Ziarek, J.J.; Uttieri, M.; Sandulli, R.; Zambianchi, E.; Strickler, J.R. Behavioural interseasonal adaptations in Daphnia pulicaria (Crustacea: Cladocera) as induced by predation infochemicals. Aquat. Ecol. 2016, 50, 667-684. [CrossRef]

58. Gutierrez, M.F.; Gagneten, A.M.; Paggi, J.C. Behavioural responses of two cladocerans and two copepods exposed to fish kairomones. Mar. Freshw. Behav. Physiol. 2011, 44, 289-303. [CrossRef]

59. Van Gool, E.; Ringelberg, J. What goes down must come up: Symmetry in light-induced migration behaviour of Daphnia. In Proceedings of the Hydrobiologia; Springer: Dordrecht, The Netherlands, 2003; Volume 491, pp. 301-307.

60. Winder, M.; Spaak, P.; Mooij, W.M. Trade-offs in Daphnia habitat selection. Ecology 2004, 85, $2027-2036$. [CrossRef]

61. Rose, K.C.; Williamson, C.E.; Fischer, J.M.; Connelly, S.J.; Olson, M.; Tucker, A.J.; Noe, D.A. The role of ultraviolet radiation and fish in regulating the vertical distribution of Daphnia. Limnol. Oceanogr. 2012, 57, 1867-1876. [CrossRef]

62. Huebner, J.D.; Young, D.L.W.; Loadman, N.L.; Lentz, V.J.; Wiegand, M.D. Age-Dependent Survival, Reproduction and Photorepair Activity in Daphnia magna (Straus, 1820) After Exposure to Artificial Ultraviolet Radiation. Photochem. Photobiol. 2006, 82, 1656. [CrossRef]

63. Ramos-Jiliberto, R.; Dauelsberg, P.; Zúñiga, L.R. Differential tolerance to ultraviolet-B light and photoenzymatic repair in cladocerans from a Chilean lake. Mar. Freshw. Res. 2004, 55, 193-200. [CrossRef]

64. Leech, D.M.; Williamson, C.E. Is tolerance to UV radiation in zooplankton related to body size, taxon, or lake transparency? Ecol. Appl. 2000, 10, 1530-1540. [CrossRef]

65. Hylander, S.; Larsson, N.; Hansson, L.A. Zooplankton vertical migration and plasticity of pigmentation arising from simultaneous UV and predation threats. Limnol. Oceanogr. 2009, 54, 483-491. [CrossRef]

66. Tollrian, R.; Heibl, C. Phenotypic plasticity in pigmentation in Daphnia induced by UV radiation and fish kairomones. Funct. Ecol. 2004, 18, 497-502. [CrossRef]

67. Loose, C.J.; Dawidowicz, P. Trade-offs in diel vertical migration by zooplankton: The costs of predator avoidance. Ecology 1994, 75, 2255-2263. [CrossRef]

68. Park, S.; Brett, M.T.; Müller-Navarra, D.C.; Goldman, C.R. Essential fatty acid content and the phosphorus to carbon ratio in cultured algae as indicators of food quality for Daphnia. Freshw. Biol. 2002, 47, 1377-1390. [CrossRef]

69. Mandal, S.; Abbott Wilkins, R.; Shurin, J.B. Compensatory grazing by Daphnia generates a trade-off between top-down and bottom-up effects across phytoplankton taxa. Ecosphere 2018, 9, e02537. [CrossRef]

70. Freese, H.M.; Martin-Creuzburg, D. Food quality of mixed bacteria-algae diets for Daphnia magna. Hydrobiologia 2013, 715, 63-76. [CrossRef] 
71. Hartwich, M.; Martin-Creuzburg, D.; Rothhaupt, K.O.; Wacker, A. Oligotrophication of a large, deep lake alters food quantity and quality constraints at the primary producer-consumer interface. Oikos 2012, 121, 1702-1712. [CrossRef]

72. Brzeziński, T.; Von Elert, E. Predator evasion in zooplankton is suppressed by polyunsaturated fatty acid limitation. Oecologia 2015, 179, 687-697. [CrossRef]

73. Isanta Navarro, J.; Fromherz, M.; Dietz, M.; Zeis, B.; Schwarzenberger, A.; Martin-Creuzburg, D. Dietary polyunsaturated fatty acid supply improves Daphnia performance at fluctuating temperatures, simulating diel vertical migration. Freshw. Biol. 2019, 64, 1859-1866. [CrossRef]

74. Wacker, A.; Von Elert, E. Polyunsaturated fatty acids: Evidence for non-substitutable biochemical resources in Daphnia galeata. Ecology 2001, 82, 2507-2520. [CrossRef]

75. Martin-Creuzburg, D.; Von Elert, E. Good food versus bad food: The role of sterols and polyunsaturated fatty acids in determining growth and reproduction of Daphnia magna. Aquat. Ecol. 2009, 43, 943-950. [CrossRef]

76. Von Elert, E. Determination of limiting polyunsaturated fatty acids in Daphnia galeata using a new method to enrich food algae with single fatty acids. Limnol. Oceanogr. 2002, 47, 1764-1773. [CrossRef]

77. Hazel, J.R. Thermal Adaptation in Biological Membranes: Is Homeoviscous Adaptation the Explanation? Annu. Rev. Physiol. 1995, 57, 19-42. [CrossRef]

78. Martin-Creuzburg, D.; Wacker, A.; Ziese, C.; Kainz, M.J. Dietary lipid quality affects temperature-mediated reaction norms of a freshwater key herbivore. Oecologia 2012, 168, 901-912. [CrossRef]

79. Gliwicz, Z.M.; Dawidowicz, P.; Maszczyk, P. Low-density anti-predation refuge in Daphnia and Chaoborus? Arch. Hydrobiol. 2006, 167, 101-114. [CrossRef]

80. Adamczuk, M. Predation follows competition in depth selection behaviour of Cladocera in a deep lake (E Poland). Biol. Lett. 2009, 46, 29-36. [CrossRef]

81. Dawidowicz, P.; Wielanier, M. Costs of predator avoidance reduce competitive ability of Daphnia. In Proceedings of the Hydrobiologia; Springer: Dordrecht, The Netherlands, 2004; Volume 526, pp. 165-169.

82. Gélinas, M.; Pinel-Alloul, B.; Ślusarczyk, M. Alternative antipredator responses of two coexisting Daphnia species to negative size selection by YOY perch. J. Plankton Res. 2007, 29, 775-789. [CrossRef]

83. Hansson, L.A.; Hylander, S. Size-structured risk assessments govern Daphnia migration. Proc. R. Soc. B Biol. Sci. 2009, 276, 331-336. [CrossRef]

84. Young, J.D.; Riessen, H.P. The interaction of Chaoborus size and vertical distribution determines predation effects on Daphnia. Freshw. Biol. 2005, 50, 993-1006. [CrossRef]

85. Wood, T.C.; Moore, P.A. Big and bad: How relative predator size and dietary information influence rusty crayfish (faxonius rusticus) behavior and resource-use decisions. Can. J. Zool. 2020, 98, 62-72. [CrossRef]

86. Watt, P.J.; Young, S. Effect of predator chemical cues on daphnia behaviour in both horizontal and vertical planes. Anim. Behav. 1994, 48, 861-869. [CrossRef]

87. Taleb, H.; Lair, N.; Reyes Marchant, P.; Jamet, J.L. Observations on vertical migrations of zooplankton at four different stations of a small, eutrophic, temperate zone lake, in relation to their predators. In Ergebnisse der Limnologie ERLIA 6-Archiv für Hydrobiologie; Schweizerbart Science Publishers: Stuttgart, Germany, 1993; pp. 199-216.

88. Van De Meutter, F.; Stoks, R.; De Meester, L. Behavioral linkage of pelagic prey and littoral predators: Microhabitat selection by Daphnia induced by damselfly larvae. Oikos 2004, 107, 265-272. [CrossRef]

89. Lindén, E.; Lehtiniemi, M.; Viitasalo, M. Predator avoidance behaviour of Baltic littoral mysids Neomysis integer and Praunus flexuosus. Mar. Biol. 2003, 143, 845-850. [CrossRef]

90. Nihan Tavşanoğlu, Ü.; Idil Çakiroğlu, A.; Erdoğan, Ş.; Meerhoff, M.; Jeppesen, E.; Beklioglu, M. Sediments, not plants, offer the preferred refuge for Daphnia against fish predation in Mediterranean shallow lakes: An experimental demonstration. Freshw. Biol. 2012, 57, 795-802. [CrossRef]

91. Gutierrez, M.F.; Molina, F.R.; Carvalho, D.A. Behavioural responses of freshwater zooplankton vary according to the different alarm signals of their invertebrate predators. Mar. Freshw. Behav. Physiol. 2013, 45, 317-331. [CrossRef]

92. Gilbert, J.J. Morphological and behavioral responses of a rotifer to the predator Asplanchna. J. Plankton Res. 2014, 36, 1576-1584. [CrossRef]

93. De Meester, L.; Pijanowska, J. On the trait-specificity of the response of Daphnia genotypes to the chemical presence of a predator. In Zooplankton: Sensory Ecology and Physiology; CRC Press: Boca Raton, FL, USA, 1996; pp. 407-417, ISBN 90-5699-022-5. 
94. Brewer, M. Interactive effects of fish kairomone and light on Daphnia escape behavior. J. Plankton Res. 1999, 21, 1317-1335. [CrossRef]

95. Chang, K.H.; Hanazato, T. Vulnerability of cladoceran species to predation by the copepod Mesocyclops leuckarti: Laboratory observations on the behavioural interactions between predator and prey. Freshw. Biol. 2003, 48, 476-484. [CrossRef]

96. Pijanowska, J.; Dawidowicz, P.; Weider, L.J. Predator-induced escape response in Daphnia. Arch. Hydrobiol. 2006, 167, 77-87. [CrossRef]

97. Szulkin, M.; Dawidowicz, P.; Dodson, S.I. Behavioural uniformity as a response to cues of predation risk. Anim. Behav. 2006, 71, 1013-1019. [CrossRef]

98. Rose, R.M.; Warne, M.S.J.; Lim, R.P. Exposure to chemicals exuded by fish reduces the filtration and ingestion rates of Ceriodaphnia cf. dubia. Hydrobiologia 2003, 501, 215-217. [CrossRef]

99. Beckerman, A.P.; Wieski, K.; Baird, D.J. Behavioural versus physiological mediation of life history under predation risk. Oecologia 2007, 152, 335-343. [CrossRef]

100. Kerfoot, W.C. Combat between predatory copepods and their prey: Cyclops, Epischura, and Bosmina. Limnol. Oceanogr. 1978, 23, 1089-1102. [CrossRef]

101. La, G.H.; Choi, J.Y.; Chang, K.H.; Jang, M.H.; Joo, G.J.; Kim, H.W. Mating behavior of Daphnia: Impacts of predation risk, food quantity, and reproductive phase of females. PLoS ONE 2014, 9, e104545. [CrossRef]

102. Sarma, S.S.S.; Dumont, H.J.; Nandini, S. Interactions between the Anomopod Cladocerans Ceriodaphnia dubia, C. cornuta, Simocephalus vetulus and S. serrulatus, the aphanoneurid worm Aeolosoma sp., and the fish Skiffia lermae: Predation or competition, or both? In Proceedings of the Hydrobiologia; Springer: Berlin/Heidelberg, Germany, 2004; Volume 526, pp. 147-156.

103. Greene, C.H. Selective Predation in Freshwater Zooplankton Communities. Int. Rev. Hydrobiol. Hydrogr. 1983, 68, 297-315. [CrossRef]

104. Dodson, S.I. Adaptive change in plankton morphology in response to size-selective predation: A new hypothesis of cyclomorphosis. Limnol. Oceanogr. 1974, 19, 721-729. [CrossRef]

105. Dodson, S.I. Cyclomorphosis in Daphnia galeata mendotae Birge and D. retrocurva Forbes as a predator-induced response. Freshw. Biol. 1988, 19, 109-114. [CrossRef]

106. Chang, K.H.; Hanazato, T. Seasonal and reciprocal succession and cyclomorphosis of two Bosmina species (Cladocera, Crustacea) co-existing in a lake: Their relationship with invertebrate predators. J. Plankton Res. 2003, 25, 141-150. [CrossRef]

107. Juračka, P.J.; Laforsch, C.; Petrusek, A. Neckteeth formation in two species of the Daphnia curvirostris complex (Crustacea: Cladocera). J. Limnol. 2011, 70, 359-368. [CrossRef]

108. Rabus, M.; Waterkeyn, A.; Van Pottelbergh, N.; Brendonck, L.; Laforsch, C. Interclonal variation, effectiveness and long-term implications of Triops-induced morphological defences in Daphnia magna Strauss. J. Plankton Res. 2012, 34, 152-160. [CrossRef]

109. Miyakawa, H.; Sugimoto, N.; Kohyama, T.I.; Iguchi, T.; Miura, T. Intra-specific variations in reaction norms of predator-induced polyphenism in the water flea Daphnia pulex. Ecol. Res. 2015, 30, 705-713. [CrossRef]

110. O'Brien, W.J.; Kettle, D.; Riessen, H. Helmets and Invisible Armor: Structures Reducing Predation from Tactile and Visual Planktivores. Ecology 1979, 60, 287-294. [CrossRef]

111. Grant, J.W.G.; Bayly, I.A.E. Predator induction of crests in morphs of the Daphnia carinata King complex. Limnol. Oceanogr. 1981, 26, 201-218. [CrossRef]

112. Tollrian, R.; Dodson, S. Inducible defenses in Cladocera: Constraints, costs, and multipredator environments. In The Ecology and Evolution of Inducible Defenses; Princeton University Press: Princeton, NJ, USA, 1999; pp. 177-202.

113. Dahm, E. Zur Biologie von Notonecta glauca (Insecta, Hemiptera) unter besonderer Berücksichtigung der fischereilichen Schadwirkung. Int. Rev. Hydrobiol. Hydrogr. 1972, 57, 429-461. [CrossRef]

114. Fryer, G. Studies on the functional morphology and biology of the Notostraca (Crustacea: Branchiopoda). Philos. Trans. R. Soc. London. B 1988, 321, 27-124. [CrossRef]

115. Havel, J.E.; Dodson, S.I. Reproductive costs of Chaoborus-induced polymorphism in Daphnia pulex. Hydrobiologia 1987, 150, 273-281. [CrossRef]

116. Dzialowski, A.R.; Lennon, J.T.; O’Brien, W.J.; Smith, V.H. Predator-induced phenotypic plasticity in the exotic cladoceran Daphnia lumholtzi. Freshw. Biol. 2003, 48, 1593-1602. [CrossRef] 
117. Amundsen, P.A.; Siwertsson, A.; Primicerio, R.; Bøhn, T. Long-term responses of zooplankton to invasion by a planktivorous fish in a subarctic watercourse. Freshw. Biol. 2009, 54, 24-34. [CrossRef]

118. Hart, R.C.; Bychek, E.A. Body size in freshwater planktonic crustaceans: An overview of extrinsic determinants and modifying influences of biotic interactions. Hydrobiologia 2011, 668, 61-108. [CrossRef]

119. Effertz, C.; Von Elert, E. Light intensity controls anti-predator defences in Daphnia: The suppression of life-history changes. Proc. R. Soc. B Biol. Sci. 2014, 281, 20133250. [CrossRef] [PubMed]

120. Effertz, C.; Von Elert, E. Coupling of anti-predator defences in Daphnia: The importance of light. Hydrobiologia 2017, 798, 5-13. [CrossRef]

121. La, G.H.; Chang, K.H.; Jang, M.H.; Joo, G.J.; Kim, H.W. Comparison of morphological defences in asexually and sexually reproduced eggs of Daphnia (D. galeata and D. similis) against fish kairomones. Russ. J. Ecol. 2014, 45, 314-318. [CrossRef]

122. Carter, M.J.; Vega-Retter, C.; Ramos-Jiliberto, R. Non-lethal effects of invertebrate predators on Daphnia: Morphological and life-history consequences of water mite kairomone. Freshw. Biol. 2008, 53, 1857-1867. [CrossRef]

123. Ma, X.; Wolinska, J.; Petrusek, A.; Gießler, S.; Hu, W.; Yin, M. The phenotypic plasticity in Chinese populations of Daphnia similoides sinensis: Recurvate helmeted forms are associated with the presence of predators. J. Plankton Res. 2016, 38, 855-864. [CrossRef]

124. Stoks, R.; Govaert, L.; Pauwels, K.; Jansen, B.; De Meester, L. Resurrecting complexity: The interplay of plasticity and rapid evolution in the multiple trait response to strong changes in predation pressure in the water flea Daphnia magna. Ecol. Lett. 2016, 19, 180-190. [CrossRef]

125. West-Eberhard, M.J. Phenotypic accommodation: Adaptive innovation due to developmental plasticity. In Proceedings of the Journal of Experimental Zoology Part B: Molecular and Developmental Evolution; Wiley: Hoboken, NJ, USA, 2005; Volume 304, pp. 610-618.

126. West-Eberhard, M.J. Developmental Plasticity and Evolution; Oxford University Press: Oxford, UK, 2003; Volume 1, pp. 1-816.

127. Harvell, C.D. The ecology and evolution of inducible defenses. Q. Rev. Biol. 1990, 65, 323-340. [CrossRef]

128. Tollrian, R. Fish-kairomone induced morphological changes in Daphnia lumholtzi (Sars). Arch. Hydrobiol. 1994, 130, 69-75.

129. Swaffar, S.M.; O'Brien, W.J. Spines of Daphnia lumholtzi create feeding difficulties for juvenile bluegill sunfish (Lepomis macrochirus). J. Plankton Res. 1996, 18, 1055-1061. [CrossRef]

130. Lindholm, M. Predator-induced cyclomorphosis of Daphnia laevis (Branchiopoda, Cladocera) in a tropical floodplain (Okavango Delta, Botswana). Crustaceana 2002, 75, 803-814. [CrossRef]

131. Engel, K.; Schreder, T.; Tollrian, R. Morphological defences of invasive Daphnia lumholtzi protect against vertebrate and invertebrate predators. J. Plankton Res. 2014, 36, 1140-1145. [CrossRef]

132. Engel, K.; Tollrian, R. Inducible defences as key adaptations for the successful invasion of Daphnia lumholtzi in North America? Proc. R. Soc. B Biol. Sci. 2009, 276, 1865-1873. [CrossRef]

133. Zaret, T.M. Predators, invisible prey, and the nature of polymorphism in the Cladocera (class Crustacea). Limnol. Oceanogr. 1972, 17, 171-184. [CrossRef]

134. Brönmark, C.; Hansson, L.A. The Biology of Lakes and Ponds; Oxford University Press: Oxford, UK, 2017; Volume 3, pp. 1-337, ISBN 9780198713593.

135. Black, A.R.; Dodson, S.I. Demographic costs of Chaoborus-induced phenotypic plasticity in Daphnia pulex. Oecologia 1990, 83, 117-122. [CrossRef]

136. Repka, S.; Walls, M.; Ketola, M. Neck spine protects Daphnia pulex from predation by Chaoborus, but individuals with longer tail spine are at a greater risk. J. Plankton Res. 1995, 17, 393-403. [CrossRef]

137. Brooks, J.L. The systematics of North American Daphnia.; Memoirs of the Connecticut Academy of Arts and Sciences-Yale University Press: New Haven, CT, USA, 1957; Volume 13, pp. 1-180.

138. Krueger, D.A.; Dodson, S.I. Embryological induction and predation ecology in Daphnia pulex. Limnol. Oceanogr. 1981, 26, 219-223. [CrossRef]

139. Havel, J.E.; Dodson, S.I. Chaoborus predation on typical and spined morphs of Daphnia pulex: Behavioral observations. Limnol. Oceanogr. 1984, 29, 487-494. [CrossRef]

140. Tollrian, R. Neckteeth formation in Daphnia pulex as an example of continuous phenotypic plasticity: Morphological effects of Chaoborus kairomone concentration and their quantification. J. Plankton Res. 1993, 15, 1309-1318. [CrossRef] 
141. Sell, A.F. Morphological defenses induced in situ by the invertebrate predator Chaoborus: Comparison of responses between Daphnia pulex and D. rosea. Oecologia 2000, 125, 150-160. [CrossRef]

142. Tollrian, R. Chaoborus crystallinus predation on Daphnia pulex: Can induced morphological changes balance effects of body size on vulnerability? Oecologia 1995, 101, 151-155. [CrossRef] [PubMed]

143. Laforsch, C.; Tollrian, R. Embryological aspects of inducible morphological defenses in Daphnia. J. Morphol. 2004, 262, 701-707. [CrossRef] [PubMed]

144. Maurone, C.; Suppa, A.; Rossi, V. Polymorphisms in predator induced defences of coexisting Daphnia pulex and D. longispina. Hydrobiologia 2018, 823, 121-133. [CrossRef]

145. Sperfeld, E.; Nilssen, J.P.; Rinehart, S.; Schwenk, K.; Hessen, D.O. Ecology of predator-induced morphological defense traits in Daphnia longispina (Cladocera, Arthropoda). Oecologia 2020, 1-12. [CrossRef]

146. Benzie, J.A.H. Cladocera: The Genus Daphnia (including Daphniopsis) (Anomopoda: Daphniidae). Guides to the Identification of the Microinvertebrates of the Continental Waters of the World, Volume 21. Q. Rev. Biol. 2005, 80, 491. [CrossRef]

147. Kotov, A.A.; Ishida, S.; Taylor, D.J. A new species in the Daphnia curvirostris (Crustacea: Cladocera) complex from the eastern Palearctic with molecular phylogenetic evidence for the independent origin of neckteeth. J. Plankton Res. 2006, 28, 1067-1079. [CrossRef]

148. Imai, M.; Naraki, Y.; Tochinai, S.; Miura, T. Elaborate regulations of the predator-induced polyphenism in the water flea Daphnia pulex: Kairomone-Sensitive periods and life-history tradeoffs. J. Exp. Zool. Part A Ecol. Genet. Physiol. 2009, 311, 788-795. [CrossRef]

149. Pastorok, R.A. Prey Vulnerability and Size Selection by Chaoborus Larvae. Ecology 1981, 62, 1311-1324. [CrossRef]

150. Laforsch, C.; Tollrian, R. Extreme helmet formation in Daphnia cucullata induced by small-scale turbulence. J. Plankton Res. 2004, 26, 81-87. [CrossRef]

151. Laforsch, C.; Ngwa, W.; Grill, W.; Tollrian, R. An acoustic microscopy technique reveals hidden morphological defenses in Daphnia. Proc. Natl. Acad. Sci. USA 2004, 101, 15911-15914. [CrossRef]

152. O'Brien, W.J.; Vinyard, G.L. Polymorphism and predation: The effect of invertebrate predation on the distribution of two varieties of Daphnia carinata in South India ponds. Limnol. Oceanogr. 1978, 23, 452-460. [CrossRef]

153. Barry, M.J.; Bayly, I.A.E. Further studies on predator induction of crests in australian daphnia and the effects of crests on predation. Mar. Freshw. Res. 1985, 36, 519-535. [CrossRef]

154. Laforsch, C.; Haas, A.; Jung, N.; Schwenk, K.; Tollrian, R.; Petrusek, A. "Crown of thorns" of Daphnia: An exceptional inducible defense discovered by DNA barcoding. Commun. Integr. Biol. 2009, 2, 379-381. [CrossRef] [PubMed]

155. Petrusek, A.; Tollrian, R.; Schwenk, K.; Haas, A.; Laforsch, C. A “crown of thorns" is an inducible defense that protects Daphnia against an ancient predator. Proc. Natl. Acad. Sci. 2009, 106, 2248-2252. [CrossRef]

156. Rabus, M.; Laforsch, C. Growing large and bulky in the presence of the enemy: Daphnia magna gradually switches the mode of inducible morphological defences. Funct. Ecol. 2011, 25, 1137-1143. [CrossRef]

157. Herzog, Q.; Rabus, M.; Ribeiro, B.W.; Laforsch, C. Inducible defenses with a "twist": Daphnia barbata abandons bilateral symmetry in response to an ancient predator. PLoS ONE 2016, 11, e0148556. [CrossRef]

158. Rabus, M.; Söllradl, T.; Clausen-Schaumann, H.; Laforsch, C. Uncovering Ultrastructural Defences in Daphnia magna-An Interdisciplinary Approach to Assess the Predator-Induced Fortification of the Carapace. PLoS ONE 2013, 8, e67856. [CrossRef]

159. Møller, O.S.; Olesen, J.; Høeg, J.T. SEM studies on the early larval development of Triops cancriformis (Bosc) (Crustacea: Branchiopoda, Notostraca). Acta Zool. 2003, 84, 267-284. [CrossRef]

160. Laforsch, C.; Tollrian, R. A new preparation technique of daphnids for Scanning Electron Microscopy using hexamethyldisilazane. Arch. Hydrobiol. 2000, 149, 587-596. [CrossRef]

161. Bungartz, B.; Branstrator, D.K. Morphological changes in Daphnia mendotae in the chemical presence of Bythotrephes longimanus. Arch. Hydrobiol. 2003, 158, 97-108. [CrossRef]

162. Branstrator, D.K. Ecological Interactions Between Bythotrephes cederstroemi and Leptodora kindtii and the Implications for Species Replacement in Lake Michigan. J. Great Lakes Res. 1995, 21, 670-679. [CrossRef]

163. Hellsten, M.; Lagergren, R.; Stenson, J. Can extreme morphology in Bosmina reduce predation risk from Leptodora? An experimental test. Oecologia 1999, 118, 23-28. [CrossRef] 
164. Chang, K.H.; Hanazato, T. Predation impact of Leptodora kindtii on population dynamics and morphology of Bosmina fatalis and B. longirostris in mesocosms. Freshw. Biol. 2004, 49, 253-264. [CrossRef]

165. Lagergren, R. Chemical cues from the invertebrate predator Leptodora kindtii affect the development of cyclomorphic traits in Eubosmina coregoni gibbera. J. Plankton Res. 2000, 22, 1213-1219. [CrossRef]

166. Chang, K.-H.; Hanazato, T. Morphological defense of Bosmina fatalis against invertebrate predators in Lake Suwa. Int. Ver. Theor. Angew. Limnol 2002, 28, 1279-1283. [CrossRef]

167. Herzig, A.; Auer, B. The feeding behaviour of Leptodora kindti and its impact on the zooplankton community of Neusiedler See (Austria). Hydrobiologia 1990, 198, 107-117. [CrossRef]

168. Jankowski, T. Predation of freshwater jellyfish on Bosmina: The consequences for population dynamics, body size, and morphology. In Proceedings of the Hydrobiologia; Springer: Berlin/Heidelberg, Germany, 2004; Volume 530-531, pp. 521-528.

169. Kerfoot, W.C. Baltic Eubosmina morphological radiation: Sensitivity to invertebrate predators (induction) and observations on genetic differences. Arch. Hydrobiol. 2006, 167, 147-168. [CrossRef]

170. Sakamoto, M.; Hanazato, T. Antennule shape and body size of Bosmina: Key factors determining its vulnerability to predacious copepoda. Limnology 2008, 9, 27-34. [CrossRef]

171. Kerfoot, W.C. Implications of copepod predation. Limnol. Oceanogr. 1977, 22, 316-325. [CrossRef]

172. Johnsen, G.H.; Raddum, G.G. A morphological study of two populations of Bosmina longispina exposed to different predation. J. Plankton Res. 1987, 9, 297-304. [CrossRef]

173. DeBeauchamp, P. Un facteur de la variabilite chez les Rotiferes du genre Brachionus. Compt. Rend. 1952, 234, 573-575.

174. Gilbert, J.J. Rotifer ecology and embryological induction. Science 1966, 151, 1234-1237. [CrossRef] [PubMed]

175. Gilbert, J.J.; Stemberger, R.S. Asplanchna-induced polymorphism in the rotifer Keratella slacki. Limnol. Oceanogr. 1984, 29, 1309-1316. [CrossRef]

176. Gilbert, J.J. Predator-specific inducible defenses in the rotifer Keratella tropica. Freshw. Biol. 2009, 54, 1933-1946. [CrossRef]

177. Nandini, S.; Perez-Chavez, R.; Sarma, S.S.S. The effect of prey morphology on the feeding behaviour and population growth of the predatory rotifer Asplanchna sieboldi: A case study using five species of Brachionus (Rotifera). Freshw. Biol. 2003, 48, 2131-2140. [CrossRef]

178. Sarma, S.S.S.; Resendiz, R.A.L.; Nandini, S. Morphometric and demographic responses of brachionid prey (Brachionus calyciflorus Pallas and Plationus macracanthus (Daday)) in the presence of different densities of the predator Asplanchna brightwellii (Rotifera: Asplanchnidae). Hydrobiologia 2011, 662, 179-187. [CrossRef]

179. Gilbert, J.J. Induction of different defences by two enemies in the rotifer Keratella tropica: Response priority and sensitivity to enemy density. Freshw. Biol. 2011, 56, 926-938. [CrossRef]

180. Gilbert, J.J. Temperature, kairomones, and phenotypic plasticity in the rotifer Keratella tropica (Apstein, 1907). Hydrobiologia 2011, 678, 179-190. [CrossRef]

181. Bernot, R.J.; Dodds, W.K.; Quist, M.C.; Guy, C.S. Temperature and kairomone induced life history plasticity in coexisting Daphnia. Aquat. Ecol. 2006, 40, 361-372. [CrossRef]

182. Boeing, W.J.; Wissel, B.; Ramcharan, C.W. Costs and benefits of Daphnia defense against Chaoborus in nature. Can. J. Fish. Aquat. Sci. 2005, 62, 1286-1294. [CrossRef]

183. Chakri, K.; Touati, L.; Alfarhan, A.H.; Al-Rasheid, K.A.S.; Samraoui, B. Effect of vertebrate and invertebrate kairomones on the life history of Daphnia magna Straus (Crustacea: Branchiopoda). C. R. Biol. 2010, 333, 836-840. [CrossRef] [PubMed]

184. Santangelo, J.M.; Soares, B.N.; Paes, T.; Maia-Barbosa, P.; Tollrian, R.; Bozelli, R.L. Effects of vertebrate and invertebrate predators on the life history of daphnia similis and moina macrocopa (Crustacea: Cladocera). Ann. Limnol. 2018, 54, 25. [CrossRef]

185. Taylor, B.E.; Gabriel, W. Optimal Adult Growth of Daphnia in a Seasonal Environment. Funct. Ecol. 1993, 7, 513. [CrossRef]

186. Taylor, B.E.; Gabriel, W. To Grow or Not to Grow: Optimal Resource Allocation for Daphnia. Am. Nat. 1992, 139, 248-266. [CrossRef]

187. Santangelo, J.M.; Bozelli, R.L.; De Esteves, F.A.; Tollrian, R. Predation cues do not affect the induction and termination of diapause in small-bodied cladocerans. Freshw. Biol. 2010, 55, 1577-1586. [CrossRef]

188. Slusarczyk, M.; Rybicka, B. Role of temperature in diapause response to fish kairomones in crustacean Daphnia. J. Insect Physiol. 2011, 57, 676-680. [CrossRef] 
189. Slusarczyk, M.; Dawidowicz, P.; Rygielska, E. Hide, rest or die: A light-mediated diapause response in Daphnia magna to the threat of fish predation. Freshw. Biol. 2005, 50, 141-146. [CrossRef]

190. Lass, S.; Vos, M.; Wolinska, J.; Spaak, P. Hatching with the enemy: Daphnia diapausing eggs hatch in the presence of fish kairomones. Chemoecology 2005, 15, 7-12. [CrossRef]

191. Waterkeyn, A.; Van Pottelbergh, N.; Vanoverbeke, J.; Vanschoenwinkel, B.; De Meester, L.; Brendonck, L. Constitutive but no Triops-induced differences in bet-hedging strategies for hatching in Daphnia. Hydrobiologia 2013, 715, 29-35. [CrossRef]

192. Mikulski, A.; Lipowska, D.; Pijanowska, J. Ontogenetic changes in Daphnia responsiveness to fish kairomone. In Proceedings of the Hydrobiologia; Springer: Dordrecht, The Netherlands, 2004; Volume 526, pp. 219-224.

193. Mikulski, A.; Pijanowska, J. When and how can Daphnia prepare their offspring for the threat of predation? Hydrobiologia 2010, 643, 21-26. [CrossRef]

194. Slusarczyk, M.; Rygielska, E. Fish faeces as the primary source of chemical cues inducing fish avoidance diapause in Daphnia magna. In Proceedings of the Hydrobiologia; Springer: Dordrecht, The Netherlands, 2004; Volume 526, pp. 231-234.

195. Wolinska, J.; Löffler, A.; Spaak, P. Taxon-specific reaction norms to predator cues in a hybrid Daphnia complex. Freshw. Biol. 2007, 52, 1198-1209. [CrossRef]

196. Beckerman, A.P.; Rodgers, G.M.; Dennis, S.R. The reaction normof size and age at maturity under multiple predator risk. J. Anim. Ecol. 2010, 79, 1069-1076. [CrossRef] [PubMed]

197. Riessen, H.P. Costs of predator-induced morphological defences in Daphnia. Freshw. Biol. 2012, 57, 1422-1433. [CrossRef]

198. Klintworth, S.; Von Elert, E. Risk of predation alters resource allocation in Daphnia under food limitation. J. Plankton Res. 2020, 42, 45-56. [CrossRef]

199. Hülsmann, S.; Vijverberg, J.; Boersma, M.; Mooij, W.M. Effects of infochemicals released by gape-limited fish on life history traits of Daphnia: A maladaptive response? J. Plankton Res. 2004, 26, 535-543. [CrossRef]

200. Relyea, R.A. How prey respond to combined predators: A review and an empirical test. Ecology 2003, 84, 1827-1839. [CrossRef]

201. Tanner, C.J.; Branstrator, D.K. Generational and dual-species exposures to invertebrate predators influence relative head size in Daphnia mendotae. J. Plankton Res. 2006, 28, 793-802. [CrossRef]

202. Laforsch, C.; Tollrian, R. Inducible defenses in multipredator environments: Cyclomorphosis in Daphnia cucullata. Ecology 2004, 85, 2302-2311. [CrossRef]

203. Wilczynski, W.; Dynak, P.; Babkiewicz, E.; Bernatowicz, P.; Leniowski, K.; Maszczyk, P. The combined effects of hypoxia and fish kairomones on several physiological and life history traits of Daphnia. Freshw. Biol. 2019, 64, 2204-2220. [CrossRef]

204. Jeyasingh, P.D.; Weider, L.J. Phosphorus availability mediates plasticity in life-history traits and predator-prey interactions in Daphnia. Ecol. Lett. 2005, 8, 1021-1028. [CrossRef]

205. Maszczyk, P.; Bartosiewicz, M. Threat or treat: The role of fish exudates in the growth and life history of Daphnia. Ecosphere 2012, 3, art91. [CrossRef]

206. Pauwels, K.; Stoks, R.; De Meester, L. Enhanced anti-predator defence in the presence of food stress in the water flea Daphnia magna. Funct. Ecol. 2010, 24, 322-329. [CrossRef]

207. Bell, A.T.C.; Murray, D.L.; Prater, C.; Frost, P.C. Fear and food: Effects of predator-derived chemical cues and stoichiometric food quality on Daphnia. Limnol. Oceanogr. 2019, 64, 1706-1715. [CrossRef]

208. Zhang, C.; Jansen, M.; De Meester, L.; Stoks, R. Energy storage and fecundity explain deviations from ecological stoichiometry predictions under global warming and size-selective predation. J. Anim. Ecol. 2016, 85, 1431-1441. [CrossRef] [PubMed]

209. Preisser, E.L.; Bolnick, D.I. The many faces of fear: Comparing the pathways and impacts of nonconsumptive predator effects on prey populations. PLoS ONE 2008, 3, e2465. [CrossRef] [PubMed]

210. Gliwicz, Z.M.; Maszczyk, P. Daphnia growth is hindered by chemical information on predation risk at high but not at low food levels. Oecologia 2007, 150, 706-715. [CrossRef] [PubMed]

211. Pietrzak, B.; Rabus, M.; Religa, M.; Laforsch, C.; Dańko, M.J. Phenotypic plasticity of senescence in Daphnia under predation impact: No ageing acceleration when the perceived risk decreases with age. R. Soc. Open Sci. 2020, 7, 191382. [CrossRef]

212. Bertram, C.R.; Pinkowski, M.; Hall, S.R.; Duffy, M.A.; Cáceres, C.E. Trait-mediated indirect effects, predators, and disease: Test of a size-based model. Oecologia 2013, 173, 1023-1032. [CrossRef] 
213. Yin, M.; Laforsch, C.; Lohr, J.N.; Wolinska, J. Predator-induced defense makes daphnia more vulnerable to parasites. Evolution 2011, 65, 1482-1488. [CrossRef]

214. Hesse, O.; Engelbrecht, W.; Laforsch, C.; Wolinska, J. Fighting parasites and predators: How to deal with multiple threats? BMC Ecol. 2012, 12, 12. [CrossRef] [PubMed]

215. Hammill, E.; Rogers, A.; Beckerman, A.P. Costs, benefits and the evolution of inducible defences: A case study with Daphnia pulex. J. Evol. Biol. 2008, 21, 705-715. [CrossRef] [PubMed]

216. Pohnert, G.; Steinke, M.; Tollrian, R. Chemical cues, defence metabolites and the shaping of pelagic interspecific interactions. Trends Ecol. Evol. 2007, 22, 198-204. [CrossRef] [PubMed]

217. Pohnert, G. Finding the fish factor. Elife 2019, 8. [CrossRef]

218. Akkas, S.B.; Kepenek, A.O.; Beklioglu, M.; Severcan, F. Molecular approach to the chemical characterization of fish-exuded kairomone: A Fourier transform infrared spectroscopic study. Aquat. Sci. 2010, 72, 71-83. [CrossRef]

219. Beklioglu, M.; Telli, M.; Gozen, A.G. Fish and mucus-dwelling bacteria interact to produce a kairomone that induces diel vertical migration in Daphnia. Freshw. Biol. 2006, 51, 2200-2206. [CrossRef]

220. Castro, B.B.; Consciência, S.; Gonçalves, F. Life history responses of Daphnia longispina to mosquitofish (Gambusia holbrooki) and pumpkinseed (Lepomis gibbosus) kairomones. In Proceedings of the Hydrobiologia; Springer: Dordrecht, The Netherlands, 2007; Volume 594, pp. 165-174.

221. Von Elert, E.; Stibor, H. Predator-mediated life history shifts in Daphnia: Enrichment and preliminary chemical characterisation of a kairomone exuded by fish. Arch. Hydrobiol. 2006, 167, 21-35. [CrossRef]

222. Weber, A. More than one "fish kairomone"? Perch and stickleback kairomones affect Daphnia life history traits differently. Hydrobiologia 2003, 498, 143-150. [CrossRef]

223. Tollrian, R.; Laforsch, C. Linking predator kairomones and turbulence: Synergistic effects and ultimate reasons for phenotypic plasticity in Daphnia cucullata. Arch. Hydrobiol. 2006, 167, 135-146. [CrossRef]

224. Heuschele, J.; Selander, E. The chemical ecology of copepods. J. Plankton Res. 2014, 36, 895-913. [CrossRef]

225. Rittschof, D.; Cohen, J.H. Crustacean peptide and peptide-like pheromones and kairomones. Peptides 2004, 25, 1503-1516. [CrossRef] [PubMed]

226. Kusch, J.; Heckmann, K. Isolation of the Lembadion-factor, A morphogenetically active signal, that induces Euplotes cells to change from their ovoid form into a larger lateral winged morph. Dev. Genet. 1992, 13, 241-246. [CrossRef]

227. Hahn, M.A.; Effertz, C.; Bigler, L.; Elert, E. Von $5 \alpha$-cyprinol sulfate, a bile salt from fish, induces diel vertical migration in Daphnia. Elife 2019, 8, e44791. [CrossRef] [PubMed]

228. Hofmann, A.F.; Hagey, L.R.; Krasowski, M.D. Bile salts of vertebrates: Structural variation and possible evolutionary signifi cance. J. Lipid Res. 2010, 51, 226-246. [CrossRef]

229. Yasumoto, K.; Nishigami, A.; Yasumoto, M.; Kasai, F.; Okada, Y.; Kusumi, T.; Ooi, T. Aliphatic sulfates released from Daphnia induce morphological defense of phytoplankton: Isolation and synthesis of kairomones. Tetrahedron Lett. 2005, 46, 4765-4767. [CrossRef]

230. Parejko, K.; Dodson, S. Progress towards characterization of a predator/prey kairomone: Daphnia pulex and Chaoborus americanus. Hydrobiologia 1990, 198, 51-59. [CrossRef]

231. Loose, C.J.; Von Elert, E.; Dawidowicz, P. Chemically-Induced Diel Vertical Migration in Daphnia-a New Bioassay for Kairomones Exuded by Fish. Arch. Hydrobiol. 1993, 126, 329-337.

232. Mikulski, A.; Czernik, M.; Pijanowska, J. Induction time and reversibility of changes in Daphnia life history caused by the presence of fish. J. Plankton Res. 2005, 27, 757-762. [CrossRef]

233. Tollrian, R.; Duggen, S.; Weiss, L.C.; Laforsch, C.; Kopp, M. Density-dependent adjustment of inducible defenses. Sci. Rep. 2015, 5, 12736. [CrossRef]

234. Hahn, M.; Von Elert, E.; Bigler, L.; Díaz Hernández, M.D.; Schloerer, N.E. $5 \alpha$-Cyprinol sulfate: Complete NMR assignment and revision of earlier published data, including the submission of a computer-readable assignment in NMReDATA format. Magn. Reson. Chem. 2018, 56, 1201-1207. [CrossRef]

235. Ringelberg, J.; Van Gool, E. Do bacteria, not fish, produce "fish kairomone"? J. Plankton Res. 1998, 20, 1847-1852. [CrossRef]

236. Pestana, J.L.T.; Loureiro, S.; Baird, D.J.; Soares, A.M.V.M. Pesticide exposure and inducible antipredator responses in the zooplankton grazer, Daphnia magna Straus. Chemosphere 2010, 78, 241-248. [CrossRef] [PubMed] 
237. Mitchell, M.D.; Bairos-Novak, K.R.; Ferrari, M.C.O. Mechanisms underlying the control of responses to predator odours in aquatic prey. J. Exp. Biol. 2017, 220, 1937-1946. [CrossRef] [PubMed]

238. Sakamoto, M.; Chang, K.H.; Hanazato, T. Plastic phenotypes of antennule shape in Bosmina longirostris controlled by physical stimuli from predators. Limnol. Oceanogr. 2007, 52, 2072-2078. [CrossRef]

239. Tuttle, L.J.; Robinson, H.E.; Takagi, D.; Strickler, J.R.; Lenz, P.H.; Hartline, D.K. Going with the flow: Hydrodynamic cues trigger directed escapes from a stalking predator. J. R. Soc. Interface 2019, 16, 20180776. [CrossRef]

240. Bernatowicz, P.; Pijanowska, J. Daphnia response to biotic stress is modified by PCBs. Ecotoxicol. Environ. Saf. 2011, 74, 711-718. [CrossRef]

241. Coors, A.; Hammers-Wirtz, M.; Ratte, H.T. Adaptation to environmental stress in Daphnia magna simultaneously exposed to a xenobiotic. Chemosphere 2004, 56, 395-404. [CrossRef]

242. DeMille, C.M.; Arnott, S.E.; Pyle, G.G. Variation in copper effects on kairomone-mediated responses in Daphnia pulicaria. Ecotoxicol. Environ. Saf. 2016, 126, 264-272. [CrossRef]

243. Hunter, K.; Pyle, G. Morphological responses of Daphnia pulex to Chaoborus americanus kairomone in the presence and absence of metals. In Proceedings of the Environmental Toxicology and Chemistry; Wiley: Hoboken, NJ, USA, 2004; Volume 23, pp. 1311-1316.

244. Mirza, R.S.; Pyle, G.G. Waterborne metals impair inducible defences in Daphnia pulex: Morphology, life-history traits and encounters with predators. Freshw. Biol. 2009, 54, 1016-1027. [CrossRef]

245. Weiss, L.C.; Pötter, L.; Steiger, A.; Kruppert, S.; Frost, U.; Tollrian, R. Rising pCO2 in Freshwater Ecosystems Has the Potential to Negatively Affect Predator-Induced Defenses in Daphnia. Curr. Biol. 2018, 28, 327-332.e3. [CrossRef]

246. Bezirci, G.; Akkas, S.B.; Rinke, K.; Yildirim, F.; Kalaylioglu, Z.; Severcan, F.; Beklioglu, M. Impacts of salinity and fish-exuded kairomone on the survival and macromolecular profile of Daphnia pulex. Ecotoxicology 2012, 21, 601-614. [CrossRef] [PubMed]

247. Riessen, H.P.; Linley, R.D.; Altshuler, I.; Rabus, M.; Söllradl, T.; Clausen-Schaumann, H.; Laforsch, C.; Yan, N.D. Changes in water chemistry can disable plankton prey defenses. Proc. Natl. Acad. Sci. USA 2012, 109, 15377-15382. [CrossRef] [PubMed]

248. Trotter, B.; Ramsperger, A.F.R.M.; Raab, P.; Haberstroh, J.; Laforsch, C. Plastic waste interferes with chemical communication in aquatic ecosystems. Sci. Rep. 2019, 9, 5889. [CrossRef] [PubMed]

249. Relyea, R.A. Predators come and predators go: The reversibility of predator-induced traits. Ecology 2003, 84, 1840-1848. [CrossRef] 